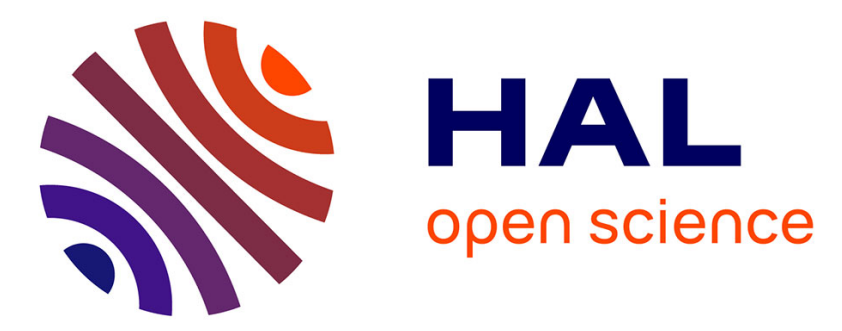

\title{
Possible (closed system) pingo and ice-wedge/thermokarst complexes at the mid latitudes of Utopia Planitia, Mars
}

\author{
R.J. Soare, S.J. Conway, J.-P. Williams, C. Gallagher, L.E. Mc Keown
}

\section{- To cite this version:}

R.J. Soare, S.J. Conway, J.-P. Williams, C. Gallagher, L.E. Mc Keown. Possible (closed system) pingo and ice-wedge/thermokarst complexes at the mid latitudes of Utopia Planitia, Mars. Icarus, 2020, 342, pp.113233. 10.1016/j.icarus.2019.03.010 . hal-02269952

\section{HAL Id: hal-02269952 \\ https://hal.science/hal-02269952}

Submitted on 5 Nov 2020

HAL is a multi-disciplinary open access archive for the deposit and dissemination of scientific research documents, whether they are published or not. The documents may come from teaching and research institutions in France or abroad, or from public or private research centers.
L'archive ouverte pluridisciplinaire HAL, est destinée au dépôt et à la diffusion de documents scientifiques de niveau recherche, publiés ou non, émanant des établissements d'enseignement et de recherche français ou étrangers, des laboratoires publics ou privés. 
Possible (closed system) pingo and ice-wedge/thermokarst complexes

at the mid latitudes of Utopia Planitia, Mars

R.J. Soare, ${ }^{1}$ S.J. Conway, ${ }^{2}$ J-P Williams, ${ }^{3}$ C. Gallagher, ${ }^{4}$ and L.E. Mc Keown ${ }^{5}$

${ }^{1}$ Geography Department, Dawson College, Montreal, QC, H3Z 1A4, Canada (rsoare@dawsoncollege.qc.ca)

${ }^{2}$ CNRS UMR 6112, LPG, Nantes, France ${ }^{3}$ Department. of Earth, Planetary and Space Sciences, University of California, Los Angeles, CA, 90095, USA

${ }^{4}$ School of Geography, University College Dublin, Belfield, Dublin 4, Ireland ${ }^{5}$ Geography Department, Trinity College Dublin, Dublin 2, Ireland

\section{Pages: 45}

Figures: 11

\section{Tables: 1}

Keywords: Mars surface, climate, ices 


\section{Abstract}

On Earth, hydrostatic or closed-system pingos $(C S P S)$ are perennial ice-cored mounds formed by the freeze-thaw cycling of water when or as thermokarst lakes lose their water by drainage or evaporation. The mounds vary in shape from circular or sub-circular to elongate, are sub-kilometre in their long axes, and may reach decametres in height. Often, the mounds show summit depressions, radial fractures and single tiers or benches. As the CSPs degrade, small-scale debris flows or slumps occur; end-stage degradation typically exhibits debris-laden ramparts elevated metres above the surrounding terrain.

Typically, the CSPS originate and develop where deep and continuous permafrost is icerich, i.e. infused with excess ice, as it is in the Tuktoyaktuk Coastlands of northern Canada, mid to northern Alaska and northeast Russia. In these areas or regions the terrain often is populated by: a) thermokarst lakes and alases (thermokarst lake basins absent of water); b) fields of small-scale ice-wedge polygons (either low-centred or high-centred relative to the polygon margins); and, c) melt-water filled or emptied polygon-margin troughs or -corner pits. Individual troughs and pits connected by means of the local topographical gradient comprises beaded stream systems or networks.

Here, we report, describe and discuss a suite of candidate $\operatorname{CSPS}$ at the mid-latitudes of Utopia Planitia $(U P)\left(\sim 35-50^{\circ} \mathrm{N} ; \sim 80-115^{\circ} \mathrm{E}\right)$. The morphologies, scale and height of the Martian mounds, as well as the surface textures and characteristics, landscape features and spatiallyassociated landforms, are consistent with the CSPS observed in ice-rich regions on Earth.

The UP mounds are nested in or reside adjacent to: flat-floored, possibly thermokarstic depressions; small-scale polygons (some of which exhibit low or high centres relative to their margins); and, connected polygon-margin depressions or pits that mirror beaded-stream systems 
in ice-rich terrain on Earth. The size-frequency distribution of craters in our study region precludes a surface younger than $\sim 100 \mathrm{Ma}$. Thus, the $C S P$-like mounds in $U P$ and the pre-mound periglacialrevisions of the landscape presented by us may be markers of freeze-thaw cycling that occurred much earlier in the Amazonian Epoch than most of the current discussions about periglaciation in $U P$ suggest.

\section{Introduction}

Here, we report, describe and evaluate the presence, distribution and possible origin of subkilometre, circular or sub-circular mounds at the mid-latitudes of Utopia Planitia $(U P)\left(\sim 35-50^{\circ}\right.$ $\left.\mathrm{N} ; \sim 80-100^{\circ} \mathrm{E}\right)$ (Fig. 1). The mounds are observed in the midst of or adjacent to relatively flatfloored and rimless depressions that may or may not be scalloped, are metres to decametres deep and, where they show spatial intersection, are kilometres in reach. Typically, the terrain within and without the depressions is polygonised. Metres-deep polygon-margin troughs or corner pits are extensive, often connected, and follow the local/regional topographical gradient, i.e. south-north. Some of the mounds exhibit metres-wide (mound-diameter) cracks; some of these cracks intercept polygon margins in the surrounding terrain.

Mounds on Earth that show similarities of shape, scale, height, surface characteristics, landscape features, and spatially-associated landforms, occur in regions of ice-rich and deep continuous permafrost. The mounds are closed-system (hydrostatic) pingos (CSPS), i.e. perennial mounds that are ice-cored and formed from the freeze-thaw cycling of near-surface water (e.g. Mackay, 1998). We propose that the candidate Martian CSPS are rooted in a cold-climate (albeit paleo-) hydrological system, akin to ice-rich periglacial landscapes on Earth where liquid water exhibits seasonal stability. 
Speculation concerning the existence of Martian pingos dates back to the Mariner and Viking missions of the 1960s and 1970s and carries through to the present day (e.g. Anderson et al., 1967, Lucchitta, 1981; Rossbacher and Judson, 1981; Parker et al., 1993; Burr et al., 2005; Soare et al., 2005; de Pablo and Komatsu, 2009; Dundas et al., 2008; Dundas and McEwen, 2010; Soare et al., 2013, 2014b). The hypothesised connexion between pingo-like mounds on Mars and ice-rich terrain is no less apparent through the deep history of Mars' remote-exploration (e.g. Anderson et al., 1967, Lucchitta, 1981; Rossbacher and Judson, 1981; Costard and Kargel, 1995; Soare et al., 2005, 2013).

Below, we: 1) describe and discuss the candidate CSPs in UP, as well the local landscapes and features that are relevant to the sustenance of our pingo hypothesis; 2) present the key geological elements of periglacial landscapes on Earth where CSPS are commonplace; and, 3) develop a landscape-scale geochronology of pingo origin and growth that is derived of possible landscape analogues on Earth but consistent with recent work on the Late Amazonian Epoch evolution of Mars.

\section{Methods}

This study surveys all of the available High Resolution Imaging Science Experiment (HiRISE), Mars Reconnaissance Orbiter (MRO) (McEwen et al., 2007) images within our study region $(N=513)$. The data-base of HiRISE sites $(n=9)$ and images $(n=12)$ relevant to our $C S P$ hypothesis is presented in Table 1. Images produced by the Mars Odyssey's Thermal Emission Imaging System (THEMIS) (Christensen et al., 2004) and the MRO's Context Camera (CTX) Malin et al., 2007) provide a regional context.

Using the Cratertools plug-in for the ESRI ArcGIS (Kneissl et al., 2011) to measure crater diameters, crater counts were conducted to characterize the surface ages and modification rates of 
the terrain incised by the rimless and sometimes scalloped depressions and populated by the pingolike mounds relative to crater production. Crater size-frequency distributions (CSFDs) were compared with crater production functions and model ages using Craterstats (Michael and Neukum, 2010) and the crater-chronology system of Hartmann (2005).

\section{Observations: pingo-like mounds and a possible "wet" periglacial landscape in Utopia} Planitia

Amidst rimless, irregularly-shaped depressions that may show scalloped morphologies, small-sized ( $\leq 100 \mathrm{~m}$ in diameter) circular or sub-circular mounds (metres to decametres in elevation) (Figs. 2a-f) are observed at the mid-latitudes of Utopia Planitia (Fig. 1); Table 1). Some of the mounds are domed (Figs. 2e-f); some of them feature summit depressions (Figs. 2b; 3a-b), of varying surface areas and depths (Figs. 2b; 3a-b); and, some of them have centres almost completely depleted of mass and elevation (above the surrounding terrain, leaving only metrescale raised rims in their wake (Fig. 3b-c). Often, the mounds host decametres-long and metreswide radial cracks (Fig. 2f). In turn, some of these cracks intercept polygon margins in the surrounding terrain (Figs. 2e-f).

The rimless depressions are metres to decametres deep (e.g. Morgenstern et al., 2007; Lefort et al., 2009; Séjourné et al., 2011) and exhibit long axes that are decametres to hundreds of metres in reach (Figs. 4a-b, d). They may be singular, dense or clustered in their distribution (Figs. 4a-b, d) and the collective reach of the depressions, where they overlap, often is kilometres in scale (e.g. Seibert and Kargel, 2001; Morgenstern et al., 2007; Soare et al., 2008; Lefort et al., 2009; Ulrich et al., 2010; Séjourné et al., 2011) (Figs. 4a-b, d).

Inward-oriented scarps (relative to the depression floors) may occur within the larger depressions (Fig. 4b); they comprise incremental losses of elevation that range from metres to 
decametres (e.g. Morgenstern et al., 2007; Soare et al., 2008; Lefort et al., 2009; Séjourné et al., 2011). The majority of scarps exhibit a poleward orientation and form on the southern margin of the depressions (e.g. Morgenstern et al., 2007; Lefort et al., 2009; Ulrich et al., 2010; Séjourné etal., 2011). A minority of scarps exhibit an equatorward orientation and form on the northern margin of the depressions (e.g. Morgenstern et al., 2007; Lefort et al., 2009; Ulrich et al., 2010; Séjourné et al., 2011). Some depressions exhibit no scarps (Fig. 4d). The number of scarps seems to be relative to the surface area and depth of the depressions, i.e. expansive and deep depressions often show multiple scarps whereas small and shallow depressions typically are absent of scarps (Lefort et al., 2009; Ulrich et al., 2010).

Typically, the depressions are incised by small-sized (metre to decametre-scale) polygons (e.g. Morgenstern et al., 2007; Soare et al., 2008; Lefort et al., 2009; Séjourné et al., 2011) (Fig. 4c). The polygonised terrain also is observed outside of or without the depressions (Figs. 4a-c). Here, the polygons are slightly larger than those observed within the depressions (Morgenstern et al., 2007; Lefort et al, 2009; Ulrich et al., 2010; Séjourné et al., 2011). Some polygons exhibit raised margins or shoulders, relative to their centres $(L C P S)$ (Fig. 4e); others show depressed margins, relative to their centres $(H C P s)$ (Fig. 4e) (Ulrich et al. 2010; Séjourné et al., 2011; Soare et al., 2018d).

Some polygon-margins exhibit fissures that are linear or sub-linear, metres wide and deep (Fig. 4c) (e.g. Wan Bun Tseung and Soare, 2006; Morgenstern et al., 2007; Lefort et al., 2009; Ulrich et al., 2010; Séjourné et al., 2011; Soare et al., 2011). Polygon-margin junctions may comprise irregular circular to sub-circular pits whose minor axes are slightly wider than the fissures or pits exhibited by the linear or sub-linear margins fissures (Fig. 4c) (e.g. Wan Bun Tseung and Soare, 2006; Morgenstern et al., 2007; Lefort et al., 2009; Ulrich et al., 2010; Séjourné 
et al., 2011; Soare et al., 2011). Some of the fissures or pits are linked spatially and trend along their north-south axes (Fig. 4e) (Wan Bun Tseung and Soare, 2006; Morgenstern et al., 2007; Lefort et al., 2009; Séjourné et al., 2010; Ulrich et al., 2010; Séjourné et al., 2011; Soare et al., 2011).

\section{Closed-system pingos, and ice-(rich) complexes on Earth}

\subsection{Closed system pingos}

In regions such as the Tuktoyaktuk Coastlands (TC) of northern Canada (e.g. Porsild, 1938; Müller, 1962; Rampton, 1988; Mackay, 1998, 1999; Samsonov et al., 2016), mid- to northern Alaska (e.g. Leffingwell, 1915; Porsild, 1938; Cabot, 1947; Hinkel et al., 2005; Wetterich et al., 2012) and northeast Russia (e.g. Schirrmeister et al., 2002, 2018; Morgenstern et al., 2013; Vasil'chuk et al., 2016; Wetterich et al. 2018), mounds that show similarities of scale, shape, morphological characteristics and landscape features to the Martian CSP-like mounds dot the landscape (Fig. 2e). These mounds - hydrostatic or closed-system pingos (CSPs) - exhibit perennial ice-cores.

Typically, the CSPS originate on the floors of thermokarst lakes emptied of their water by drainage or evaporation (Figs. 5a-b) and develop as the newly-exposed lake floors undergo subaerial freezing, either diurnally or seasonally. Iteratively, this engenders the downward propagation and aggradation of permafrost, impelling pore-water away from the freezing fronts and towards the remaining pockets of unfrozen ground (e.g. Mackay, 1998, 1999; Walker and Jorgenson, 2011) (Fig. 5a). As the hydrostatic pressure of the pore-water increases, the sedimentary overburden, i.e. formerly, the lake floor, begins to deform and uplift, creating a domelike mound (Figs. 5b-c). As the pore-water freezes an ice core forms (Figs. 5a, e). 

hundreds of metres (Fig. 2e) (e.g. Washburn, 1973; Mackay, 1998, 1999; French, 2007). Pingo shape, usually circular to sub-circular (Figs. 2e, 5b-d), is determined by the morphology or bathymetry of the lake floors or basins in which they are nested (e.g. Washburn, 1973; Mackay, 1998, 1999; French, 2007).

Amongst larger pingos, metres wide and deep fissures, i.e. dilation cracks, are not unusual (Figs. 2e, 5d). These cracks propagate and trend from the mound summit as the pingo grows and tensile stresses increase within the sedimentary overburden (e.g. Washburn, 1973; Mackay, 1998, 1999; French, 2007). Sometimes, these cracks grade into the surrounding polygonised terrain (Mackay, 1998).

As the cracks widen and deepen, the ice core's sedimentary overburden stretches and thins. This increases the likelihood of thaw penetration, thermal instability and the subsequent formation of a summit depression or pit as the ice core ablates (Figs. 2e; 5d) (Mackay, 1998). The ongoing exposure of the ice core to thaw may engender thaw slumps and/or small-scale debris flows. A slightly-elevated, sometimes irregular rampart represents the end-stage of pingo evolution (Fig. 5g) (Mackay, 1998). Amassed debris sometimes covers these ramparts (Washburn, 1973).

\subsection{Ice complexes}

Ice complexes comprise metre- to decametre-thick sequences or horizons of fine-grained, ice-rich sediments that have accumulated by means of fluvial, glacial, fluvio-glacial or aeolian processes (Figs. 6a-i). Ice-enrichment occurred during the disparate warming periods of the Holocene Epoch. Invariably, the periglacial regions populated by the CSPS also exhibit ice complexes and cryologically-related landforms, i.e. thermokarst and alases, ice veins and icewedge polygons, beaded-drainage networks, etc (the TC: Rampton and Bouchard, 1974; Rampton, 
1988; French, 2007; Grosse et al., 2007; Morgenstern et al., 2007, 2013; Schirrmeister et al., 2002, 2013; and northeast Russia: e.g. Czudek and Demek, 1970; Schirrmeister et al., 2002, 2013; Grosse et al., 2007).

Permafrost is ice-rich if and when it contains excess ice, i.e. the volume of ice in the ground that exceeds the total pore-volume that the ground would have under unfrozen conditions (e.g. Harris et al., 1988; also, see Taber, 1930; Penner, 1959; Rampton and Mackay, 1971; Washburn, 1973; Murton, 1996; Rampton, 1988; French, 2007). Excess ice may comprise ice lenses, veins, wedges or larger masses of consolidated ice formed by ice segregation. Fine to medium-grained soils such as silts or silty clays are particularly adept at hosting segregation ice because they have relatively-small interstices. Small interstices facilitate the migration of pore water by cryosuction and the formation of discrete layers or lenses of segregation ice at the freezing front (Taber, 1930; Penner, 1959; Rampton and Mackay, 1971; Rampton, 1988; French, 2007).

Thermokarst refers to terrain in regions of ice-rich permafrost that undergoes frost heave and settlement in response to the volumetric aggradation or degradation of excess ice. Frost heave occurs as segregated-ice forms and aggrades (Taber, 1930; Penner, 1959; Rampton, 1988). Frost settlement occurs when segregation-ice thaws or degrades and the host terrain settles under its own weight until it reaches a consolidated state (Harris et al., 1988). Frost heave and settlement occur seldomly where the terrain is ice poor and exhibits only ice cement between sedimentary grains (Péwé, 1954).

Thaw-derived meltwater may pool; this creates a transient lake or pond. The total loss of lake or pond water by drainage or evaporation engenders the formation of a thermokarstic depression absent of water, i.e. an alas (Washburn, 1973; Rampton, 1988; French, 2007). If the loss is partial and episodic, then inwardly-oriented benches or terraces may develop on the alas 
margins; this would give the margins a distinctly-scalloped appearance (e.g. Brown et al., 1981; Soare et al., 2008, 2011).

Spatially, the formation of thermokarst lakes and alases in an ice-rich landscape delineate the depth, breadth and scale of thermal disequilibrium, i.e. the sustained rise of sub-aerial mean (summer) temperatures (e.g. Péwe, 1954; Anderson and Hussey, 1963; French, 2007; Grosse et al., 2007; Schirrmeister et al., 2013; Wetterich et al., 2014), as well as ice loss (e.g. Czudek and Demek, 1970; Rampton and Mackay, 1971; Washburn, 1973, Rampton, 1988; French, 2007). Alas valleys, individual depressions that have conjoined as they have grown over time, comprise kilometres of reach and are meso-scale markers of thermal disequilibrium in an ice-rich landscape (e.g. Czudek and Demek, 1970; French, 2007).

\subsection{Polygonised terrain}

Small-sized (generally $\leq 25 \mathrm{~m}$ in diameter) and non-sorted polygons are observed wherever thermokarst landforms populate the landscape (e.g. Lachenbruch, 1962; Mackay, 1972; 1999; Czudek and Demek 1970; Rampton and Bouchard 1974; Rampton, 1988; French, 2007) (Figs. 6ce). The polygons are produced by the tensile-induced fracturing that arises from the sharp drop of sub-zero $\left(0^{\circ} \mathrm{C}\right)$ temperatures in frozen ground (Lachenbruch 1962). This fracturing, referred to as thermal-contraction cracking, initially forms shallow vertical and horizontal fissures or cracks that are scattered across the landscape.

Crack fill, depending on the ambient environmental-conditions and the relative availability of atmospheric, surface/near-surface water, or of wind-blown soil/sand, comprises one of three types. 1) Seasonally-produced meltwater derived of thawed snow or ice, ubiquitous in the relatively mild and humid Tuktoyaktuk Coastlands (Figs. 6c, g); 2) winter hoarfrost; and, 3) windblown sand (Figs. 6f-g), mineral-soil, or a mixture of the two (e.g. de Leffingwell 1915; Péwé 
1959; Lachenbruch 1962; Washburn 1973; Sletten et al. 2003; Hallet et al. 2011). The seasonal iteration of thermally-induced cracking and crack filling eventually modifies the shallow and narrow veins into deeper and wider cracks. As thermal-contraction cracks propagate through a landscape they intersect and form polygon networks, often on a multi-kilometre scale (e.g. Black 1952; Lachenbruch 1962; Washburn 1973; Mackay 1974) (Figs. 6d-e). Typically, the diameters of thermal-contraction cracks range from 5-40 m (Washburn 1973; French 2007).

If underlain by aggrading ice-wedges then the polygon margins may display raised shoulders, relative to the polygon centres or to the terrain's elevation-datum, and are referenced as low-centred polygons (LCPs) (Washburn 1973; Harris et al., 1988; Rampton, 1988; French 2007; Fig. 6e). Ice-wedges undergoing thaw (degradation) may exhibit collapsed shoulders, relative to the polygon centres, and are referenced as high-centred polygons (HCPs) (Washburn 1973; Harris et al., 1988; Rampton, 1988; French 2007) Figs. 6c-g). Spatially-associated assemblages of $L C P S / H C P s$ are not uncommon wherever closed-system pingos are observed and, as with the presence of thermokarst in a landscape, denote the ubiquity of liquid water and of active freezethaw cycling on a local if not a regional scale (e.g. Rampton and Bouchard, 1974; Rampton, 1988; Mackay, 1972, 1974).

Sand-wedge polygons (SWPS) also are observed in thermokarst landscapes (e.g. Mackay and Matthews, 1983; Murton et al., 2000) (Figs. 6f-g). They are paleo-markers of climatic, hydrological and aeolian regimes that differ markedly, i.e. drier and/or colder, from the regimes associated with the origin and development of ice-wedge polygons, i.e. slightly warmer, wetter and less active, be they LCPs or HCPs (Washburn, 1973; Mackay and Matthews, 1983; Murton et al., 2000; Wolfe et al., 2018). 

that arises when ice wedges aggrade or degrade is more subtle or muted in the case of the SWPS.

This is to be expected. The volumetric gain or loss of soil space engendered by the freeze-thaw cycling (ice-wedge aggradation/degradation) is greater (+/-9\%) than the gain or loss of soil space when sand is added or removed from a wedge site. Moreover, the volumetric potential of water to migrate from a thaw zone by means of surface or through flow is higher than the potential of sand to be removed from a wedge site purely by the work of wind.

Outcrops of low and high-centred sand-wedge polygons, albeit spatially-disassociated, also develop in the extreme aridity and low temperatures of the McMurdo Dry Valleys (MDVs), Antarctica (e.g. Péwé, 1959; Lachenbruch, 1962; French and Guglielmin, 2000; Marchant et al., 2002; Sletten et al., 2003; Hallett et al., 2011). Here, similarly to the LCPs and HCPs that populate wet periglacial-landscapes in the northern hemisphere, the formation of both polygon types is initiated by thermal contraction (e.g. Péwé, 1959; Lachenbruch, 1962; French and Gugliemin, 2000; Marchant et al., 2002; Sletten et al., 2003; Hallett et al., 2011).

Further development also follows a similar path of aggradation and degradation, i.e. soil deforms upwardly $(L C P s)$ as sandy wedge-fill accumulates by the work of wind and deforms downwardly $(L C P s)$ as the sandy fill is removed from the wedge site by the work of wind (e.g. Péwé, 1959; Lachenbruch, 1962; French and Gugliemin, 2000; Marchant et al., 2002; Sletten et al., 2003; Hallett et al., 2011). Sometimes, development of the HCPs is enhanced by the sublimation of underlying glacial ice (Marchant et al., 2002).

Although ice-rich terrain within one metre of the surface has been reported in the $M D V s$ (Lacelle et al., 2011,2013), none of the locations where the $L C P s$ or the HCPs are observed exhibit thermokarst, ice-wedging or beaded streams (French and Gugliemin, 2000; Marchant et al., 2002; 
Sletten et al., 2003; Hallett et al., 2011). Moreover, whether or not the ice-rich terrain formed by means of freeze-thaw or adsorption/diffusion cycles is unclear (Lacelle et al., 2011).

\subsection{Small-scale "beaded-stream" systems}

Where ice wedges degrade and thaw, deflating raised polygon-shoulders below the elevation datum of the polygon centres, marginal troughs or corner pits may form and collect icewedge derived meltwater (e.g. Lawson, 1986; Walker and Jorgenson, 2011; Arp et al., 2012, 2015; Tarbeeva and Surkov, 2013) (Figs. 7a-d). Prolonged or iterative periods of thaw increase the volume of meltwater in the troughs and pits, as well as in the surrounding terrain (Lachenbruch 1966; Arp et al., 2015).

Over time, the local topographical-gradient provides direction and drop for initiallyisolated pockets of meltwater to join (Anderson and Hussey, 1963; Arp et al., 2015; King et al., 2016) (Figs. 7a-b, d). This spatial coalescence forms the permafrost-based equivalent of a firstorder stream (Anderson and Hussey, 1963; Arp et al., 2012, 2015; Tarbeeva and Surkov, 2013) whose reach eventually may comprise decametres to kilometres of surface coverage (Lawson, 1986; French, 2007; Walker and Jorgenson, 2011; Tarbeeva and Surkov, 2013) (Figs. 7c-d). Second, polygon-trough corners or junctions comprise multiple paths of possible meltwatermigration and surface-flow, providing for higher rates of accumulation and thermal erosion than linear or sub-linear marginal troughs. Thus, the junction pools exhibit greater depths to their floors and surface areas than do the troughs (Péwé, 1954; Anderson and Hussey, 1963).

\section{A possible geochronology of $C S P$ formation at the mid-latitudes of Utopia Planitia}

\subsection{An icy origin}

Atmospherically precipitated ice/snow accumulates at the mid-latitudes of the northern hemisphere, perhaps the result of Late Amazonian Epoch changes of obliquity and eccentricity 
302

303

304

305

306

307

308

309

310

311

312

313

314

315

316

317

318

319

320

321

322

323

324

(e.g. Mustard et al., 2001; Head et al., 2003; Milliken et al., 2003; Morgenstern et al., 2007; Lefort et al., 2009; Madeleine et al. 2009; Séjourné et al., 2011). Remnants of the most recent atmospherically-precipitated mantle, possibly an icy one, are observed throughout the region (e.g. Mustard et al. 2001; Head et al., 2003; Milliken et al., 2003; Morgenstern et al., 2007; Schorghofer, 2007; Lefort et al., 2009; Soare et al., 2015; 2018a) (Figs. 8a-c). The mantle shows a relativelylight tone (relative to the underlying terrain), smooth texture (at HiRISE resolution) and, often, is unpolygonised (Soare et al., 2015; 2018b-c).

A densely-cratered basement underlies the relatively dark and the light-toned terrains and is observed where overlying materials are relatively thin. The basement is old relative to the time scales of the recent obliquity and eccentricity changes (Figs. 9a-c). Crater counts of visible rims from this underlying surface indicate the crater population is in saturation equilibrium. This is consistent with a Noachian-aged surface. However, the overlying darker-toned material is cratered sparsely. The size-frequency distribution of the craters is indicative of a surface that has been modified as it has a shallow power-law slope. This is the consequence of fewer meter-to-decametre scale craters than predicted from crater-production functions (e.g. Hartmann, 2005). The number of $\sim 100 \mathrm{~m}$ craters, contrarily, precludes a surface younger than $\sim 100 \mathrm{Ma}$. The craters on this surface have a subdued, shallow appearance, lacking rims and ejecta similar to the heavilydegraded craters, or hollows, observed by the Mars Exploration Rovers (e.g. Grant et al., 2006; Golombek et al., 2014). Thus, the low density of craters is the result of crater degradation and is not indicative of a youthful surface (e.g. Smith et al., 2008; Kite and Mayer, 2017; Williams et al., 2018). From this, we can infer that the age probably is not younger than $\sim 100 \mathrm{Ma}$, although an absolute age cannot be derived.

\subsection{Periglacial revisions and the collapse of thermokarst}


A less-than-recent icy mantle (unobserved but inferred from the cyclical nature of mantle formation (e.g. Mustard et al.., 2001; Head et al., 2003; Milliken et al., 2003; Schorghofer, 2007; Madeleine et al., 2009) undergoes freeze-thaw cycling of ice/snow. Meltwater migrates through the relatively dark-toned and possibly fine-grained volcanic regolith to depth (Soare et al., 2015). Excess ice develops, i.e. ice lenses, veins, wedges or larger masses of consolidated ice, as the meltwater undergoes freeze-thaw cycling (Sizemore et al., 2015; Soare et al., 2015; 2018) and thermokarst forms (Soare et al., 2018a, b).

Blanketed by a sublimation lag, the thermal integrity of thermokarst at the mid-latitudes is maintained for a period of time (e.g. Mellon and Jakosky, 1993; Mustard et al., 2001; Milliken et al., 2003; Dundas et al., 2015; Dundas, 2017). As the amplitude of mean surface-temperatures and atmospheric-humidity vary in response to cyclical changes of obliquity (Laskar and Robutel 1993; Touma and Wisdom 1993; Laskar et al., 2004), the near-surface excess ice sublimates; this mass loss triggers terrain deflation and, if sufficiently substantial, the formation of a thermokarstic depression (Dundas et al., 2015; Dundas, 2017). Inward-oriented benches or scarps (Figs. 4a-b) form in response to the episodicity of mass loss and comprise paleo-markers of individual periods of climate change (e.g. Morgenstern et al., 2007; Lefort et al., 2009; Ulrich et al, 2010; Séjourné et al., 2011; Soare et al., 2011, 2018a, b).

\subsection{Polygonisation and beaded pit/trough assemblages}

As the regional landscape undergoes this cryological evolution, thermal-contraction cracking polygonises the terrain episodically (e.g. Costard and Kargel, 1995; Seibert and Kargel, 2001; Morgenstern et al., 2007; Soare et al., 2008, 2011; Lefort et al., 2009; Levy et al., 2009; Madeleine et al. 2009; Ulrich et al., 2010; Séjourné et al., 2011) (Fig. 4). Differences in the structural complexity of the polygon networks, i.e. the density of secondary vs primary cracks in 
a polygon and or the disparity between polygon diameters within the depressions and those observed without, are paleo-markers of this episodicity (Lefort et al., 2009; Ulrich et al., 2010; Séjourné et al., 2011).

Some of the polygons exhibit high centres, relative to their margins; elsewhere, the polygons express low centres, relative to their margins (Figs. 4d-e). Differences in polygon centremargin morphologies are not an unequivocal marker of ice-wedging, as disparate non-icy types of fill could underlie raised or lowered polygon margins (Figs. 6f-g).

However, if the two polygon types are observed in the midst of landscapes that exhibit a multiplicity of geological weaves with possible ice-richness and the freeze-thaw cycling of water, then deducing an ice-wedge origin for the lcps or hcps is not unjustifiable (Wan Bun Tseung and Soare, 2006; Soare, Conway and Dohm 2014; Soare et al. 2018a). This is the case especially where lcps and hcps are observed in proximity, as the origin of the two distinct but spatially-associated polygon-morphologies or types could be explained most simply by transient (triple-point of water) boundary conditions.

Similarly, the small-scale and spatially-associated polygon-margin troughs and corner pits that are observed within and without the rimless and sometimes scalloped depressions could be the degradational artefacts of ice-wedging (Figs. $\mathbf{4 b}$-c). In other words, as the near-surface ice wedges sublimate, cavities or voids develop in the regolith; this engenders the deflation or collapse of the overburden (Wan Bun Tseung and Soare, 2006, Séjourné et al., 2010; 2011; Soare et al., 2011, Glines and Gulick, 2018; also, Costard et al., 2016). Collectively, the beaded appearance and spatial connectivity of the troughs and corner pits are similar to that which is observed on Earth wherever thermokarst and ice wedges are undergoing the loss of thermal integrity (Wan Bun Tseung and Soare, 2006, Soare et al., 2011, Costard et al., 2016; Glines and Gulick, 2018). 
The dominant topographical-gradient in $U P$ is east-west. However, there is a more subtle

downslope trend that runs from the southern highlands to the pole (e.g. Zuber et al., 1998; Hiesinger and Head, 2000), especially where the polygonised terrain is observed (Hiesinger and Head, 2000). The alignment of the polygon troughs and pits is consistent with the second gradient.

\subsection{Ice mound formation}

Warming conditions, driven by recent changes of obliquity and eccentricity and facilitated, perhaps, by the presence of brines in the regolith (e.g. Primm et al., 2017; Jones, 2018), induces the: a) thaw of residual excess-ice in the near surface; and, b) pooling of meltwater beneath the scalloped terrain. Subsequent freezing-conditions trigger permafrost aggradation in the nearsurface of the scalloped terrain, promoting the growth of an ice-cored mound. Dilation cracks form at the summit as the overburden stretches with mound growth. The cracks may grade radially towards the surrounding terrain and, as in pingo-dotted landscapes on Earth, intercept the polygons surrounding them. Summit depressions and elevationally-depleted mound centres also are observed (Figs. 2a-b; 3a-d); they may be markers of ice-core degradation as regional temperatures rise and the active layer deepens.

\section{Non-periglacial origins of the rimless and sometimes scalloped depressions and mounds?}

\subsection{Thermokarst and sublimation?}

Within the community of Mars planetary-researchers there is a widespread agreement that the rimless and sometimes scalloped depressions at the mid-latitudes of $U P$ are thermokarst (e.g. Costard and Kargel, 1995; Seibert and Kargel, 2001; Morgenstern et al., 2007; Soare et al., 2008, 2018a,b; Lefort et al., 2009; Ulrich et al., 2010; Séjourné et al., 2011; Dundas et al., 2015; Dundas, 2017). No less widespread is the belief that the loss of excess ice probably is the work of sublimation (e.g. Costard and Kargel, 1995; Seibert and Kargel, 2001; Morgenstern et al., 2007; 
Soare et al., 2018a,b; Lefort et al., 2009; Ulrich et al., 2010; Séjourné et al., 2011; Dundas et al., 2015; Dundas, 2017).

The $M D V s$ in the Antarctic exhibit some icy landscape-features that could have been revised by sublimation (e.g. Marchant et al., 2002; Kowaleski et al., 2006; Lacelle et al., 2011, 2013). For example, buried and ancient glacial-ice in Beacon Valley, one of the $M D V s$, may undergo highly-localised sublimation where the terrain is incised by thermal-contraction cracking and the cracks migrate through polygon troughs in the glacial overburden to the underlying ice. At the University Valley, adjacent to the Beacon Valley, water vapour condensation/diffusion is invoked to explain the past formation of excess ice in the upper few centimetres of the soil as seasonal temperatures and atmospheric vapour-pressures have varied seasonally within the last $\sim 135 \mathrm{ka}$ (Lacelle et al., 2011, 2013).

The sub-metre horizons of the excess ice in the $M D V s$ are significantly thinner, by at least two orders of magnitude (Lacelle et al., 2011, 2013), than the deepest thermokarst-like depressions on Mars. This could be an empirical constraint, in as much as sublimation-tolerant conditions occur for significantly shorter time periods on Earth than on Mars; or, there could be a theoretical constraint on the propagation depths of adsorption/diffusion cycles. Modelling shows that the accumulation of adsorbed ice in the near-surface pore space would choke the subsequential transfer of vapour to lower layers (Clifford, 1993; Mellon and Jakosky, 1993; also, Dundas et al., 2015). Either way, most thermokarst landscapes and ice complexes on Earth have evolved in environments largely absent of sublimation (Dundas et al., 2015).

On the other hand, there is no inconsistency in hypothesising a freeze-thaw origin for excess ice and thermokarst (Soare et al., 2017, 2018a, b), be it on Earth or on Mars, while acknowledging that sublimation is responsible for the voiding of excess ice in the near-surface 
417

wherever the thermokarstic depressions are observed in our study region. The former assumes slightly different triple-point conditions than the latter, and defers to the only recognised means by which excess ice could form to decametres of depth.

\subsection{The pingo-like mounds}

Numerous researchers have reported the possible presence of kilometre-and sub-kilometre scale pingos in Utopia Planitia and have evaluated disparate formation-hypotheses for the candidate mounds (Morgenstern et al., 2007; Osinski and Soare, 2007; Dundas et al., 2008; Burr et al., 2009; de Pablo and Komatsu, 2009; Soare and Osinski, 2009; Dundas and McEwen, 2010; Soare et al., 2013a). Here, we describe, discuss and contrast two sub-kilometre mound-types that share the greatest number of similarities with closed-system pingos on Earth, a) intra-crater, variable in shape and banded; and, b) flat topped, typically circular and fractured. These two mound-types are commonplace in the region studied by us and often occur in close spatialassociation with the mounds interpreted by us to be CSPs. For a broader discussion of all smallscale mound types in the region, see Burr et al., (2009).

\subsubsection{Intra-crater mounds (ICMs)}

Sub-kilometre mounds rooted in kilometre-and sub-kilometre scale impact craters (Figs. 10a-b) are ubiquitous at the mid latitudes of $U P$ (Soare et al., 2013; also, Morgenstern et al., 2007; Osinski and Soare, 2007; Soare and Osinski, 2009; Dundas and McEwen, 2010). Mound morphologies are wide-ranging, i.e. circular and sub-circular to crescentic, and, distribution, generally, is clustered (Fig. 10a) (Soare et al., 2013; also, Soare and Osinski, 2009; Dundas and McEwen, 2010). Volumetrically, the ratio of mound-surface to crater-basin area varies from high (basin filling) to low (barely observable) (Dundas and McEwen, 2010; Soare et al., 2013a) (Fig. 10a). Some of the mounds show metre to decametre-scale (in elevation) single or multiple terraces, 
immediately adjacent to but topographically lower than the mound summits (Figs. 10a-b). This could be indicative of differential accumulation and erosion derived of texturally-disparate strata, i.e. loess, ice dust or volcanic sediments (Soare et al., 2013a).

Some of the mound summits are domed (Fig. 10b); some of them show metres-scale pitting, as does the terrain adjacent to the mounds on the crater floor (Dundas and McEwen, 2010) (Figs. 10a-b). Contrarily, neither the mounds nor the adjacent terrain are polygonised (Soare and Osinski, 2009). However, where the crater-nested mounds are observed within the thermokarstic depressions, the adjacent terrain may show polygonisation (Soare and Osinski, 2009).

\subsubsection{Flat-topped mounds (FTMs)}

Sub kilometre mounds that are circular to sub-circular with flat mesa-like summits and steep sides are ubiquitous in the region, often in terrain shared with the ICMs (Dundas et al., 2008; Dundas and McEwen, 2010; Figs. 11a-d). Some of the mounds display multiple fractures, one or two of which may be prominent, i.e. slightly wider and deeper than the others (Dundas and McEwen, 2010). Many of the fractures are diametrical and some of the fractures extend to the surrounding terrain, intersecting polygons incised therein (Figs. 11b-c). The FTMs are observed in polygonised or in metre-scale pitted terrain and they themselves may be pitted. None of the observed mounds, however, exhibit the substantial variance of shape associated with the ICMs. Nor do they show the range of possible degradational features associated with the candidate CSPS.

\section{A periglacial origin?}

7.1 Martian pingos and periglaciation

We propose that the geological, geomorphological and analogue-derived fit between wetbased periglaciation and the candidate CSPs is closer and more plausible than the alternatives: 
a) It is generally agreed that the flat-floored, rimless and sometimes scalloped depressions at the mid-latitudes of $U P$ are thermokarstic and that they are embedded in ice-rich terrain to depth. On Earth, ice-rich terrain to depth occurs only where liquid water is abundant at or near the surface and where the freeze-thaw cycling of this water dominates (or has dominated) the regional landscape.

b) Whether or not the polygons in the region are underlain by ice or sand wedges is openended. However, the following geological constraints favour an origin based on the freeze-thaw cycling of water. First, the spatial synonymy of the polygons with the thermokarst-like and possibly ice-rich or depleted depressions. Second, the adjacency of lcps and hcps at some candidate CSP sites, possibly suggesting transitional albeit highly localised triple-point conditions. Third, spatial assemblages of polygon-margin troughs and corner pits. In permafrost regions on Earth similar assemblages point to the episodic thaw of ice-wedge polygons, sometimes on a regional scale.

c) In addition to being nested in thermokarstic depressions the Martian mounds show synonymy with CSPS on Earth across a broad spectrum of geological traits and landscape features: similarity of scale and shape, domed summits, summit depressions and summit fractures, possible degradation and end-stage morphologies; adjacency to polygonised terrain (that may comprise $L C P s$ and/or $H C P s$ ) and to polygon-margin troughs and corner pits that could be analogous to beaded-stream systems.

\subsection{Alternatives}

We propose that the dissimilarities between the ICMs and the candidate CSPs in UP, let alone between the ICMs in UP and CSPs on Earth, are sufficiently abundant to discount a periglacial origin for the former. 
First, the ICMs exhibit intra-crater morphologies that vary from almost crater-filling to crescentic, with the latter often being observed in the eastern/northeastern quadrant of the moundbearing impact craters (Soare et al., 2013a). The suggestion has been made that the large range or variance of morphologies associated with the ICMs could be the result of sedimentary accumulation and aeolian erosion, possibly dominated by prevailing winds from the southeast (Soare et al., 2013a; Steele et al., 2018). The candidate CSPs exhibit no similarity of morphological range or variance or more than one level of terracing.

Second, the relatively-pristine shape of the crescentic ICMs and their terraces, i.e. being unbroken or modified by slumping or debris flows, points away from the possible presence of a buried or underlying ice-core. Were the ICMS actually ice-cored mounds overlain by sediments, the stripping away of the sedimentary overburden by aeolian activity would increase the ice-core's sensitivity to ablation. As the ice-core ablates the loss of mass would engender the collapse of the core overburden. This, in turn, would initiate small-scale slumping and debris flows (Mackay, 1998) (Fig. 6c). No apparent debris flows or slumps, however, are observed either on the terraces or the slopes of the ICMs.

The FTMs, by contrast, share a number of traits with the candidate CSPs. First, they exhibit similarities of scale and, often, of circular or sub-circular shape. Second, they are incised by diametrical cracks or fissures. Third, they are observed, although not exclusively, in polygonised terrain. On the other hand 1) the range of morphologies possibly associated with ice-core degradation are absent from the FTMs, as they are with the ICMs; and, 2) the FTMs are observed, almost exclusively, away from the thermokarstic depressions and, sometimes, in terrain that is unpolygonised and absent of the polygon-margin and corner-pit depression assemblages.

\section{Discussion and Conclusion}




\subsection{Ice-rich terrain and the freeze-thaw cycling of water on Mars}

As early as the Mariner missions fifty years or so ago Mars-focused planetary scientists noted that the partial pressure of water vapour at the surface of Mars generally is below the triple point of water (e.g. Anderson et al., 1967; Sharp et al., 1971; Sharp, 1973). In as much as the origin and development of ice-rich landscape complexes require water stability or, minimally, iterative meta-stability, this was troubling for scientists reporting ice-complex like features and landforms on Mars (e.g. Anderson et al., 1967; Sharp et al., 1971; Sharp, 1973; Lucchitta, 1981; Theilig and Greeley, 1979; Rossbacher and Judson, 1981).

However, well before the recent observations and experimental findings about briny freezing-point depressants at/near the Martian surface and diurnal temperatures/pressures above the triple point at all Martian latitudes (e.g. Haberle et al., 2001; Hecht, 2002; Chevrier et al., 2009; Chevrier et al., 2012; Ohja et al., 2015; Primm et al. 2017; Jones, 2018), it was thought that diliquescent salts or brines could:

a) enhance the water-vapour sorption capacity of soil (Anderson et al., 1967, also, Rossbacher and Judson, 1981), especially if that soil comprises relatively small-grains, i.e. clays (Anderson et al., 1967); and,

b) facilitate the development of ice-rich thermokarst, i.e. terrain that swells and contracts as ice lenses form and sublimate or evaporate (e.g. Anderson et al., 1967; Sharp et al., 1971; Sharp, 1973; Lucchitta, 1981).

It should also be noted that wet periglacial-landscapes on Earth form episodically and that the stability of liquid water where this happens need not be exhibited uniformly through the course of a calendar year. Favourable boundary-conditions expressed for a few hours diurnally and seasonally suffice. For example, in 1978 Mackay $(1997,1999)$ drained a thermokarst lake 
artificially at Richards' Island in the $T C$. Within six years of this drainage, and through the accompanying diurnal/seasonal periods of thaw-freeze cycling, he observed the origin and development of metre-sized mounds with radii from $\sim 15-25 \mathrm{~m}$ and small ice-wedge polygons beginning to form on the lake floor (Mackay, 1997, 1999).

\subsection{Remote reasoning}

Absent of boots on the ground and a pick or shovel, the attempt to validate the CSP hypothesis requires deducing process from landscape and moving probabilistically between Earth and Mars-based geological systems:

a) Broadly speaking, the proposed geochronology of landscape evolution at the midlatitudes of $U P$, as well as the need for icy material to initiate the freeze-thaw cycling of water at the mid-latitudes where the candidate CSPS are observed, are in line with recent work on obliquity-driven atmospheric precipitation and surface accumulation.

b) Even in the light of current Martian boundary-condition, the temperature and pressure requirements of water undergoing episodic freeze-thaw cycling in our study region are not implausible. This is true particularly under a soil regime where brines are commonplace (e.g. Jones, 2018) and diurnal periods of meta-stability are hours-long (Primm et al., 2017).

c) The relative location of the candidate CSPs within the rimless and sometimes scalloped depressions, as well as the similarity between the UP mounds and terrestrial CSPs in scale, height, shape, range of shape variance, surface fractures, domed summits, summit depressions, polygonisation, proximity to assemblages of linear and beaded polygon-margins, and fracturing, are consistent with a "wet" periglacial origin. 
In and of themselves, some of the geological predicates identified above need not be the

product of water undergoing freeze-thaw cycling, i.e., a) polygons whose margins are underlain by sand; or, b) the thermokarst-like depressions being devolatilised by sublimation, etc. Occam's razor, however, points in another direction. On the other hand, the origin and development of the candidate $C S P s$ in $U P$ is explained most simply by a tightly-weaved set of geological observations and a landscape-scale hypothesis driven by a single process, i.e. the freeze-thaw cycling of water. Alternative explanations, while "drier" and possibly credible on lesser scales of analysis, lack the overall robustness of a "wetter" hypothesis.

\section{References}

Anderson, D.M., Gaffney, E.S., Low, P.F., 1967. Frost phenomena on Mars. Science 155, 3760, 319-322, doi:10.1126/science.155.3760.319.

Anderson, G.S., Hussey, K.M., 1963. Preliminary Investigation of Thermokarst Development on the North Slope, Alaska. Proceedings of the Iowa Academy of Science 70, 55, 306-320.

Arp, C.D., Whitman, M.S., Jones, B.M., Kemnitz, R., Grosse, G., Urban, F.E., 2012. Drainage network structure and hydrologic behavior of three lake-rich watersheds on the Arctic Coastal Plain, Alaska. Arctic, Antarctic, and Alpine Research 44, 4, 385-398, doi.org/10. $1657 / 1938-4246-44.4 .385$.

Arp, .C.D. Whitman, M.S., Jones, B.M., Grosse, G., Gaglioti, B.V., Hei, K.C., 2015. Distribution and biophysical processes of beaded streams in Arctic permafrost landscapes. Biogeosciences, 12, 29-47, doi:10.5194/bg-12-29-2015.

Black, R.F., 1952. Polygonal patterns and ground conditions from aerial photographs. Photogrammetric Engineering 18, 1, 123-134.

Brown, R.J.E., Johnston, G.H., Mackay, J.R., Morgenstern, N.R., Shilts, W.W., 1981. Permafrost 
distribution and terrain characteristics, in (ed.) G.H. Johnson, Permafrost, Engineering Design and Construction, 31-72.

Burr, D.M., Soare, R.J., Wan-Bun Tseung, J.M., Emery, J.P., 2005. Young (late Amazonian) nearsurface ground-ice features near the equator. Icarus 178, 1, 56-73, doi.org/10.1016/2005. 04.012 .

Burr, D.M., Bruno, B.C., Lanagan, P.D., Glaze, L.S., Jaeger, W.L., Soare, R.J., Wan Bun Tseung, J-M., Skinner, J.S., Baloga, S.M., 2009. Mesoscale raised rim depressions (MRRDs) on Earth: A review of the characteristics, processes, and spatial distributions of analogs for Mars. Planetary and Space Science 57, 479-596, doi:10.1016/j.pss.2008.11.011.

Cabot, E.C., 1947. The Northern Alaskan Coastal Plain interpreted from aerial photographs. Geographical Review 37, 4, 639-648.

Chevrier, V.F., Hanley, J., Altheide, T.S., 2009. Stability of perchlorate hydrates and their liquid solutions at the Phoenix landing site, Mars. Geophysical Research Letters 36, L10202, doi.org/10.1029/2009GL037497.

Chevrier, V.F., Rivera-Valentin, E.G., 2012. Formation of recurring slope lineae by liquid brines on present-day Mars, 39, L21202, doi.org/10.1029/2012GL054119

Clifford, S.M., 1993. A Model for the hydrologic and climatic behavior of water on Mars. Journal of Geophysical Research 98, E6, 10,973-11,106.

Christensen, P.R., et al. 2004. The Thermal Emission Imaging System (THEMIS) for the Mars Odyssey mission. Space Science Review, 110, 85-130.

Costard, F., Kargel, J.S., 1995. Outwash plains and thermokarst on Mars. Icarus 114, 93-112.

Costard, F., Séjourné, A., Kargel, J.S., Godin, E., 2016. Modeling and observational occurrences 
of near-surface drainage in Utopia Planitia, Mars. Geomorphology 275, 80-89, dx.doi.org/10.1016/j.geomorph.2016.09.034.

Czudek, T., Demek, J., 1970. Thermokarst in Siberia and its influence on the development of lowland relief. Quaternary Research 1, 103-120.

De K Leffingwell, E. 1915. The Canning River Region, Northern Alaska. USGS Professional Paper 109, $251 \mathrm{p}$.

de Pablo, M.A., Komatsu, G., 2009. Possible pingo fields in the Utopia basin, Mars: Geological and climatical implications. Icarus 199, 1, 49-74, doi.org/10.1016/j.icarus.2008.09.007.

Dundas, C.M., 2017. Effects of varying obliquity on Martian sublimation thermokarst landforms. Icarus 281, 115-120, dx.doi.org/10.1016/j.icarus.2016.08.031.

Dundas, C.M., Byrne, S., 2010. Modeling sublimation of ice exposed by new impacts in the martian mid-latitudes. Icarus 206, 716-728, doi:10.1016/j.icarus.2009.09.007.

Dundas, C.M., McEwen, A.S., 2010. An assessment of evidence for pingos on Mars using HiRISE. Icarus 205, 244-258, doi:10.1016/j.icarus.2009.02.020.

Dundas, C.M., Mellon, M.T., McEwen, A.S., Lefort, A., Keszthelyi, L.P., Thomas, N., 2008. HiRISE observations of fractured mounds: Possible martian pingos. Geophysical Research Letters 35, L04201, doi.org/10.1029/2007GL031798.

Dundas, C.M., Byrne, S., McEwen, A.S., 2015. Modeling the development of martian sublimation thermokarst landforms. Icarus 262, 154-169, dx.doi.org/10.1016/j.icarus.2015.07.033.

French, H.M., Guglielmin, M., 2000. Frozen ground phenomena in the vicinity of Terra Nova Bay, Northern Victoria land, Antarctica: a preliminary report. Geografiska Annaler $82 \mathrm{~A}$, 513-526.

French, H.M., 2007. The periglacial environment, West Sussex, England, J. Wiley \& Sons, 458 
621

622

623

624

625

626

627

628

629

630

631

632

633

634

635

636

637

638

639

640

641

642

643

p.

Glines, N.H., Gulick, V.C., 2018. Thermokarst paleolake assemblages and channels in Lyot Crater, Mars. 49th LPSC, abstract \# 2955, Houston, Texas.

Golombek, M.P., Warner, N.H., Ganti, V., Lamb, M.P., Parker, T.J., Fergason, R.L., Sullivan. R., 2014. Small crater modification on Meridiani Planum and implications for erosion rates and climate change on Mars, Journal of Geophysical Research, 119, 2522-2547, doi:10. 1002/2014JE004658.

Grant, J.A., et al. 2006. Crater gradation in Gusev crater and Meridiani Planum, Mars, Journal of Geophysical Research, 111, E02S08, doi:10.1029/2005JE002465.

Grosse, G., Schirrmeister, L., Siegert, C., Kunitsky, V.K., Slagoda, E.A., Andreev, A.A., Dereviagyn, Y., 2007. Geological and geomorphological evolution of a sedimentary periglacial landscape in northeast Siberia during the late Quaternary. Geomorphology 86, 25-51, doi:10.1016/j.geomorph.2006.08.005.

Haberle, R.M., McKay, C.P., Schaeffer, J., Cabrol, N.A., Grin, E., Zent, A.P., Quinn, R., 2001. On the possibility of liquid water on present day Mars. Journal of Geophysical Review 106, E10, 23,317-23,326.

Hallet, B., Sletten, R., Whilden, K., 2011. Micro-relief development in polygonal patterned ground in the Dry Valleys of Antarctica. Quaternary Research 75, 347-355, doi.org/10. 1016/j.yqres.2010.12.009.

Harris, S.A., French, H.M., Heginbottom, J.A., Johnston, G.H., Ladanyi, B., Dego, D.C., van Everingen, R.O., 1988. Technical Memorandum. 142, Permafrost Subcommittee, National Research Council, 154 p.

Hartmann, W.K., 2005. Martian cratering 8: Isochron refinement and the chronology of Mars. 
644

645

646

647

648

649

650

651

652

653

654

655

656

657

658

659

660

661

662

663

664

665

Icarus 174, 294-320, doi:10.1016/j.icarus.2004.11.023.

Head, J.W., Mustard, J.F., Kreslavsky, M.A., Milliken, R.E., Marchant, D.R., 2003. Recent ice ages on Mars. Nature 426, 797-802, doi:10.1038/nature02114.

Hecht, M.H., 2002. Metastability of liquid water on Mars. Icarus 156, 373-386, doi:10.1006/icar. 2001.6794.

Hecht, M.H., 2009. Detection of Perchlorate and the Soluble Chemistry of Martian Soil at the Phoenix Lander Site. Science 325, 5936, 64-67, doi:10.1126/science.1172 466.

Hiesinger, H., Head, J.W., 2000. Characteristics and origin of polygonal terrain in southern Utopia Planitia, Mars: Results from Mars Orbiter Laser Altimeter and Mars Orbiter Camera data. Journal of Geophysical Research 105, E5, 11,999-12,022.

Hinkel. K.M., Frohn, R.C., Nelson, F.E., Eisner, W.R., Beck, R.A., 2005. Morphometric and spatial analysis of thaw lakes and drained thaw lake basins in the Western Arctic Coastal Plain, Alaska. Permafrost and Periglacial Processes 16, 327-341, doi:10.1002/ ppp.532.

Jones, E., 2018. Shallow transient liquid water environments on present-day Mars, and their implications for life. Acta Astronautica 146, 144-150, doi.org/10.1016/j.actaastro.2018.02. 027.

Kite E.S., Mayer D.P., 2017. Mars sedimentary rock erosion rates constrained using crater counts, with applications to organic-matter preservation and to the global dust cycle. Icarus 286:212-222, doi.org/10.1016/j.icarus.2016.10.010.

King, T.V., Neilson, B.T., Levi, Overbeck, L.D., Kane, D.L., 2016. Water temperature controls in low arctic rivers, Water Resources Research 52, 4358-4376, doi:10.1002/2015WR017965.

Kneissl, T., van Gasselt, S., Neukum, G., 2011. Map-projection-independent crater size-frequency 
determination in GIS environments - New software tool for ArcGIS. Planetary and Space Science 59, 1243-1254, doi.org/10.1016/j.pss.2010.03.015.

Kowalewski, D.E., Marchant, D.R., Levy, J.S., Head, J.W., 2006. Quantifying low rates of summer-time sublimation for buried glacier ice in Beacon Valley. Antarctica. Antarctic Science 18 3, 421-428, doi:10.1016/j.geomorph.2010.11.001.

Lacelle, D., Davila, A.F., Fisher, D., DeWitt, R., Pollard, W.H., Andersen, D., Heldmann, J., Marinova, M.M., McKay, C.P., 2011. Vapour diffusion origin (condensation-adsorption) in ice cemented permafrost spanning the last 135.5 ka years in University Valley, Dry Valleys of Antarctica. $5^{\text {th }}$ International Conference on Mars Polar Science and Exploration, Fairbanks, Alaska, Abstract \# 6083.

Lacelle, D., Davila, A.D., Fisher, D., Pollard, W.H., DeWitt, R., Heldmann, J., Marinova, M.M., McKay, C.P., 2013. Excess ground ice of condensation-diffusion origin in University Valley, Dry Valleys of Antarctica: Evidence from isotope geochemistry and numerical modeling. Geochimica et Cosmochimica Acta 120, 280-297, dx.doi.org/10.1016/j.gca. 2013.06.032.

Lachenbruch, A.H., 1962. Mechanics of thermal contraction cracks and ice-wedge polygons in permafrost. GSA Special Paper 70. Geological Society of America, New York, 69 p.

Lachenbruch, A.H., 1966. Contraction theory of ice-wedge polygons: a qualitative discussion, Permaforst International Conference, Lafayette, Indiana, 63-70.

Laskar, J., Correia, A.C.M., Gastineau, M., Joutel, F., Levrard, B., Robutel, P., 2004. Long term evolution and chaotic diffusion of the insolation quantities of Mars. Icarus 170, 343-364, doi.org/10.1016/j.icarus.2004.04.005.

Laskar, J., Robutel, P., 1993. The chaotic obliquity of the planets. Nature 361, 608-612. 
Lawson, D.E., 1986. Response of permafrost terrain to disturbance: a synthesis of observations from Northern Alaska, U.S.A. Arctic and Alpine Research 18, 1, 1-17.

Lefort, A. Russell, P.S., Thomas, N., McEwen, A.S., Dundas, C.M., Kirk, R.L., 2009. Observations of periglacial landforms in Utopia Planitia with the High Resolution Imaging Science Experiment (HiRISE) Journal of Geophysical Review 114, E04005, doi:10.1029/ 2008JE003264.

Levy, J.S., Head, J., Marchant, D. 2009. Thermal contraction crack polygons on Mars: Classification, distribution, and climate implications from HiRISE observations. Journal of Geophysical Research 114, E01007, doi:10.1029/2008JE003273.

Lucchitta, B., 1981. Mars and Earth: Comparison of cold-climate features. Icarus 45, 264-303.

Mackay, J.R., 1972. The world of underground ice. Annals of the Association of American Geographers 62, 1, 1-22.

Mackay, J.R., 1974. Ice wedge cracks, Garry Island, Northwest Territories, Canadian Journal of Earth Science 11, 1366-1383.

Mackay, J.R., 1978. A full-scale field experiment (1978-1995) on the growth of permafrost by means of lake drainage, western Arctic coast: a discussion of the method and some results. Canadian Journal of Earth Sciences 34, 17-33.

Mackay, J.R., Matthews, J.V., 1983. Pleistocene ice and sand wedges, Hooper Island, Northwest Territories. Canadian Journal of Earth Sciences 20, 1087-1098.

Mackay, J.R., 1998. Pingo growth and collapse, Tuktoyaktuk Peninsula areas, western arctic coast, Canada: a long-term field study. Géographie physique et Quaternaire 52, 3, 1-53. Mackay, J.R., 1999. Periglacial features developed on the exposed lake bottoms of seven 
lakes that drained rapidly after 1950, Tuktoyaktuk Peninsula Area, western arctic coast, Canada. Permafrost and Periglacial Processes. 10, 39-63.

Madeleine, J-B., Forget, F., Head, J.H., Levrard, B., Montmessin, F., Millour, E., 2009. Amazonian northern mid-latitude glaciation on Mars: A proposed climate scenario Icarus 203, 390-405, doi:10.1016/j.icarus.2009.04.037.

Malin, M.C., et al., 2007. Context Camera investigation on board the Mars Reconnaissance Orbiter. Journal of Geophysical Research 112, E05S04. doi:10.1029/ 20 06JE0 02808.

Marchant, D.R. et al., 2002. Formation of patterned ground and sublimation till over Miocene glacier ice in Beacon Valley, southern Victoria Land, Antarctica. Geological Society of America Bulletin 114, 6, 718-730.

McEwen, A.S., et al., 2007. Mars Reconnaissance Orbiter's High Resolution Imaging Science Experiment (HiRISE). Journal of Geophysical Research 112, E05S02, doi:10.1029/2005/ JE002605.

Mellon, M.T., Jakosky, B.M., 1993. Geographic variations in the thermal and diffusive stability of ground ice on Mars. Journal of Geophysical Research 98, E2, 3345-3364.

Michael, G.G., Neukum, G., 2010. Planetary surface dating from crater size-frequency distribution measurements: partial resurfacing events and statistical age uncertainty. Earth and Planetary Science Letters 294, 223-229, doi:10.1016/j.eps1.2009.12.041.

Milliken, R.E., Mustard J.F., Goldsby, D.L., 2003. Viscous flow features on the surface of Mars: Observations from high-resolution Mars Orbiter Camera (MOC) images. Journal of Geophysical Research 108, E6, 5057, doi:10.1029/2002JE002005.

Morgenstern, A., Hauber, E., Reiss, D., van Gasselt, S., Grosse, G., Schirrmeister, L., 2007. 
Deposition and degradation of a volatile-rich layer in Utopia Planitia and implications for climate history on Mars. Journal of Geophysical Research 112, E06010, doi:10.1029/2006 JE002869.

Morgenstern, A., Ulrich, M., Günther, F., Roessler, S., Fedorova, I.V., Rudaya, N.A., Wetterich, S., Boike, J., Schirrmeister, L., 2013. Evolution of thermokarst in East Siberian ice-rich permafrost: a case study. Geomorphology 201, 363-379, doi.org/10.1016/j.geomorph. 2013.07.011.

Müller, F., 1962. Analysis of some stratigraphic observations and radiocarbon dates from two pingos in the Mackenzie Delta area, N.W.T. Arctic 15, 4, 279-288.

Murton, J.B., 1996. Thermokarst-lake basin sediments, Tuktoykatuk Coastlands, western arctic Canada. Sedimentology 43, 737-760.

Murton, J.B., 2005. Ground-ice stratigraphy and formation at North Head, Tuktoyaktuk Coastlands, Western Arctic Canada: a product of glacier-permafrost interactions. Permafrost and Periglacial Processes 16, 31-50, doi:10.1002/ppp.513.

Murton, J.B., Worsley, P., Gozdsik, J., 2000. Sand veins and wedges in cold aeolian environments. Quaternary Science Reviews 19, 899-922.

Mustard, J.F., Cooper, C.D., Rifkin, M.K., 2001. Evidence for recent climate change on Mars from the identification of youthful near-surface ground ice. Nature 412, 411-414, doi:10. $1038 / 35086515$.

Ohja, L., Wilhelm, M.B., Murchie, S.L., McEwen, A.S., Wray, J.J., Hanley, J., Massé, M., Chojnacki, M., 2015. Spectral evidence for hydrated salts in recurring slope lineae on Mars. Nature Geoscience 8, 829-832, doi.org/10.1038/ngeo2546.

Osinski, G.R., Soare, R.J., 2007. Circular structures in Utopia Planitia, Mars: impact vs periglacial 
origin and implications for assessing ground ice content. $38^{\text {th }}$ Lunar and Planetary Science Conference, Houston, Texas. Abstract \# 1609.

Parker, T.J., Gorsline, D.S., Saunders, R.S., Pieri, D.S., Schneeberger, D.M., 1993. Coastal geomorphology of the Martian northern plains. Journal of Geophysical Research 98, E6, $11,061-11,078$

Penner, E., 1959. The mechanism of frost heaving in soils. Highway Research Board Bulletin 225, $1-22$.

Péwé, T.L., 1954. Effect of permafrost on cultivated fields, Fairbanks area, Alaska. U.S. Geological Survey Bulletin 989-F, 315-351.

Péwé, T.L., 1959. Sand-wedge polygons (tessellations) in the McMurdo Sound region, Antarcticaa progress report. American Journal of Science 257, 545-552.

Porsild, A.E., 1938. Earth mounds in unglaciated arctic northwestern America. Geographical Review, 28, 1, 46-58.

Primm, K.M., Gough, R.V., Chevrier, V.F., Tolbert, M.A., 2017. Freezing of perchlorate and chloride brines under Mars-relevant conditions. Geochimica et Cosmochimica Acta 212, 211-220, dx.doi.org/10.1016/j.gca.2017.06.012.

Rampton, V.N., 1988. Quaternary geology of the Tuktoyaktuk Coastlands, Northwest Territories, Geological Society of Canada, Memoir 423, 98 p.

Rampton, V.N., Mackay, J.R., 1971. Massive ice and icy sediments throughout the Tuktoyaktuk Peninsula, Richards Island, and nearby areas, District of Mackenzie, Geological Survey of Canada, Paper 71-21, 16 p.

Rampton, V.N., Bouchard, M., 1974. Surficial geology of Tuktoyaktuk, District of Mackenzie. Geological Survey of Canada, Paper 74-53, 17 p. 
Rossbacher, L.R., Judson, S., 1981. Ground ice on Mars: inventory, distribution and resulting landforms. Icarus 45, 35-59.

Samsonov, S.V., Lantz, T.C., Kokelj, S.V., Zhang, Y., 2016. Growth of a young pingo in the Canadian arctic observed by RADARSAT-2 interferometric satellite radar. Cryosphere 10, 799-810, doi:10.5194/tc-10-799-2016.

Schirrmeister, L., Siegert, C., Kunitzky, V.V., Grootes, P.M., Erlenkeuser, H., 2002. Late Quaternary ice-rich permafrost sequences as a paleoenvironmental archive for the Laptev Sea Region is northern Siberia. International Journal of Earth Sciences 91, 154-167, doi:10.1007/s005310100205.

Schirrmeister, L., Froese, D., Tumskoy, V., Grosse, G. \& Wetterich, S., 2013. Yedoma: late Pleistocene ice-rich syngenetic permafrost of Beringia. In: Elias, S.A., (ed.) The Encyclopedia of Quaternary Science 3, 542-552. Amsterdam: Elsevier.

Schirrmeister, L., Bobrov, A., Raschke, E., Herzschuh, U., Strauss, J., Pestryakova, L.A., Wetterich, S., 2018. Late Holocene ice-wedge polygon dynamics in northeastern Siberian coastal lowlands. Arctic, Antarctic, and Alpine Research, 50, 1, e1462595, doi:10.1080/ 15230430.2018 .1462595 .

Schorghofer, N., 2007. Dynamics of ice ages on Mars. Nature 192-195, 449, doi:10.1038/nature 06082.

Seibert, N.M., Kargel, J.S., 2001. Small scale Martian polygonal terrain: implications for liquid surface water. Geophysical Research Letters 28, 5, 899-902.

Séjourné, A. Costard, F.N., Gargani, J., Soare, R.J., Marmo, C., 2010. The polygon junction pits as evidence of a particularly ice-rich area of Utopia Planitia. $41^{\text {st }}$ Lunar and Planetary Science Conference, Houston, Texas. Abstract \# 2113. 
802

803

804

805

806

807

808

809

810

811

812

813

814

815

816

817

818

819

820

821

822

Séjourné, A. Costard, F.N., Gargani, J., Soare, R.J., Federov, A., Marmo, C., 2011. Scalloped terrain and small-sized polygons in western Utopia Planitia, Mars: a new formation hypothesis. Planetary and Space Science 59, 412-422, doi:10.1016/j.pss.2011.01.007.

Sharp, R.P., Soderblom, L.A., Murray, B.C., Cutts, J.A., 1971. The surface of Mars, uncratered terrain. Journal of Geophysical Research 76, 2, 331-342.

Sharp, R.P., 1973. Mars: fretted and chaotic terrains. Journal of Geophysical Review 78, 20, 40734083.

Sizemore, H. G., Zent, A.P., Rempel, A.W., 2015. Initiation and growth of Martian ice lenses. Icarus 251, 191-210, doi.org/10.1016/j.icarus.2014.04.013.

Sletten, R.S., Hallet, B., Fletcher, R.C., 2003. Resurfacing time of terrestrial surfaces by the formation and maturation of polygonal patterned ground. Journal of Geophysical Research 108, E4, 8044, dx.doi.org/10.1029/2002JE001914.

Smith, M.R., Gillespie, A.R., Montgomery, D.R., 2008. Effect of obliteration on crater count chronologies for Martian surfaces. Geophysical Research Letters 35, L10202, doi:10.1029/2008GL033538.

Soare, R.J., Burr, D.M., Wan Bun Tseung, J-M., 2005. Pingos and a possible periglacial landscape in northwest Utopia Planitia, Mars. Icarus 174, 373-382, doi.org/10.1016/j. icarus.2004.11. 013.

Soare, R.J., Osinski, G.R., Roehm, C.L., 2008. Thermokarst lakes and ponds on Mars in the very recent (late Amazonian) past. Earth and Planetary Science Letters 1-2, 382-393, doi.org/ 10.1016/j.eps1.2008.05.010.

Soare, R.J., Osinski, G.R. 2009. Stratigraphical evidence of late Amazonian periglaciation and 
glaciation in the Astapus Colles region of Mars. Icarus 202, 17-21, doi:10.1016/j.icarus. 2009.02.009.

Soare, R.J., Séjourné, A., Pearce, G., Costard, F., Osinski, G.R., 2011. The Tuktoyaktuk coastlands of northern Canada: a possible "wet" periglacial analogue of Utopia Planitia, Mars. Geological Society of America 483, 203-218, doi.org/10.1130/2011.2483(13).

Soare, R.J., Conway, S.J., Pearce, G.D., Costard, F., Séjourné, A., 2013a. Sub-kilometre (intracrater) mounds in Utopia Planitia, Mars: character, occurrence and possible formation hypotheses. Icarus 225, 982-991, dx.doi.org/10.1016/j.icarus.2012.06.003.

Soare, R.J., Conway, S.J, Pearce, G., Dohm, J.M., Grindrod, P.M., 2013. Possible crater-based pingos, paleolakes and periglacial landscapes in the high latitudes of Utopia Planitia, Mars. Icarus, 225, 2, 971-981, doi.org/10.1016/j.icarus.2012.08.041.

Soare, R.J., Conway, S.J., Dohm, J.M., 2014a. Possible ice-wedge polygons and recent landscape modification by "wet" periglacial processes in and around the Argyre impact basin, Mars Icarus 225, 2, 971-981, doi.org/10.1016/j.icarus.2012.08.041.

Soare, R.J., Conway, S.J., Dohm, J.M., El-Maarry, M.R., 2014b. Possible open-system pingos in and around the Argyre impact basin, Mars. Earth and Planetary Science Letters 398, 2536, doi.10.1016/j.eps1.2014.04.044.

Soare, R.J., Horgan, B., Conway, S.J., Souness, C., El-Maarry, M.R., 2015. Volcanic terrain and the possible periglacial formation of "excess ice" at the mid-latitudes of Utopia Planitia, Mars. Earth and Planetary Science Letters 423, 182-192, dx.doi.org/10.1016/j.eps1.2015. 04.033 .

Soare, R.J., Conway, S.J., Gallagher, C., Dohm, J.M., 2017. Ice-rich (periglacial) vs icy (glacial) 


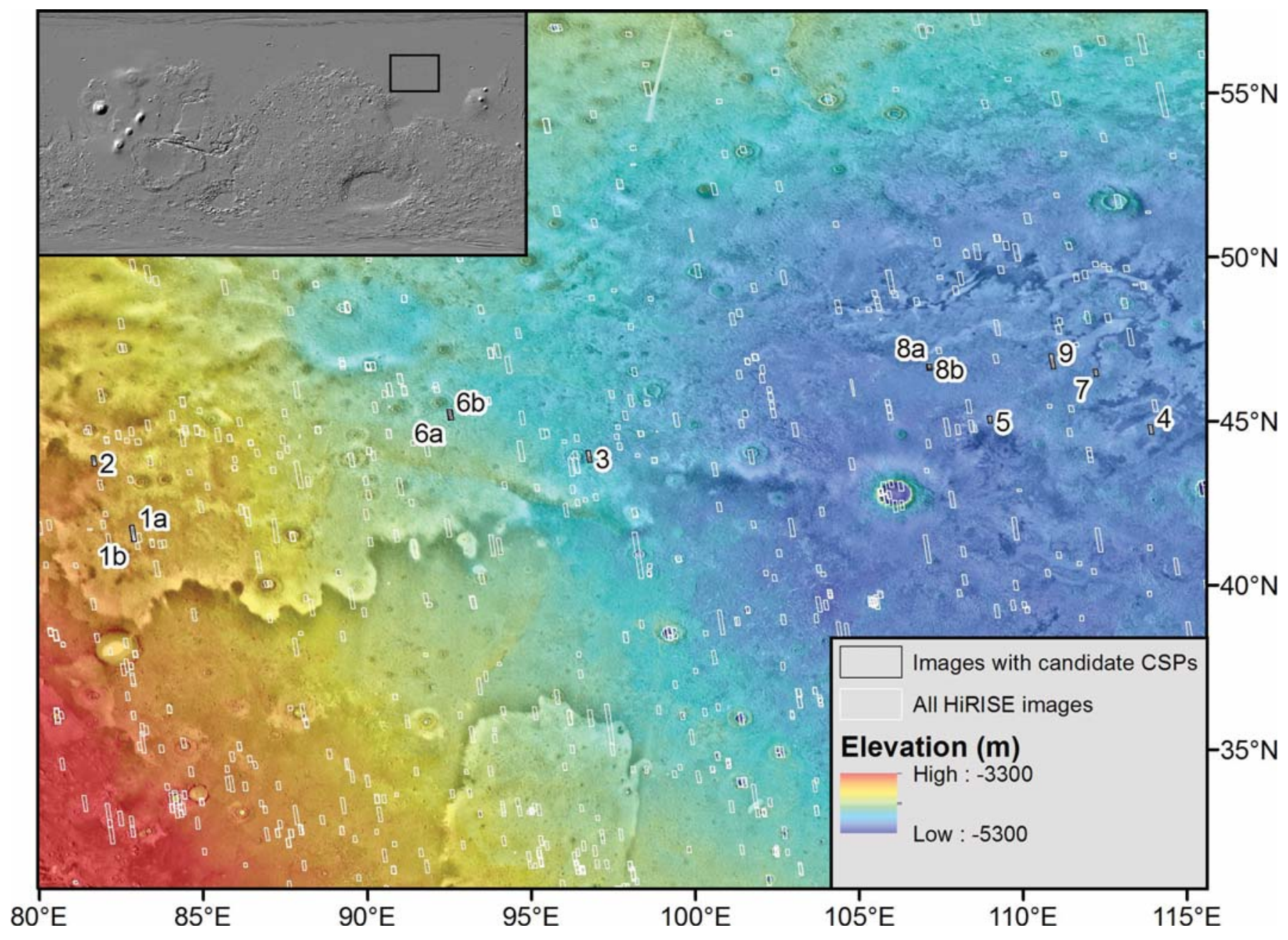




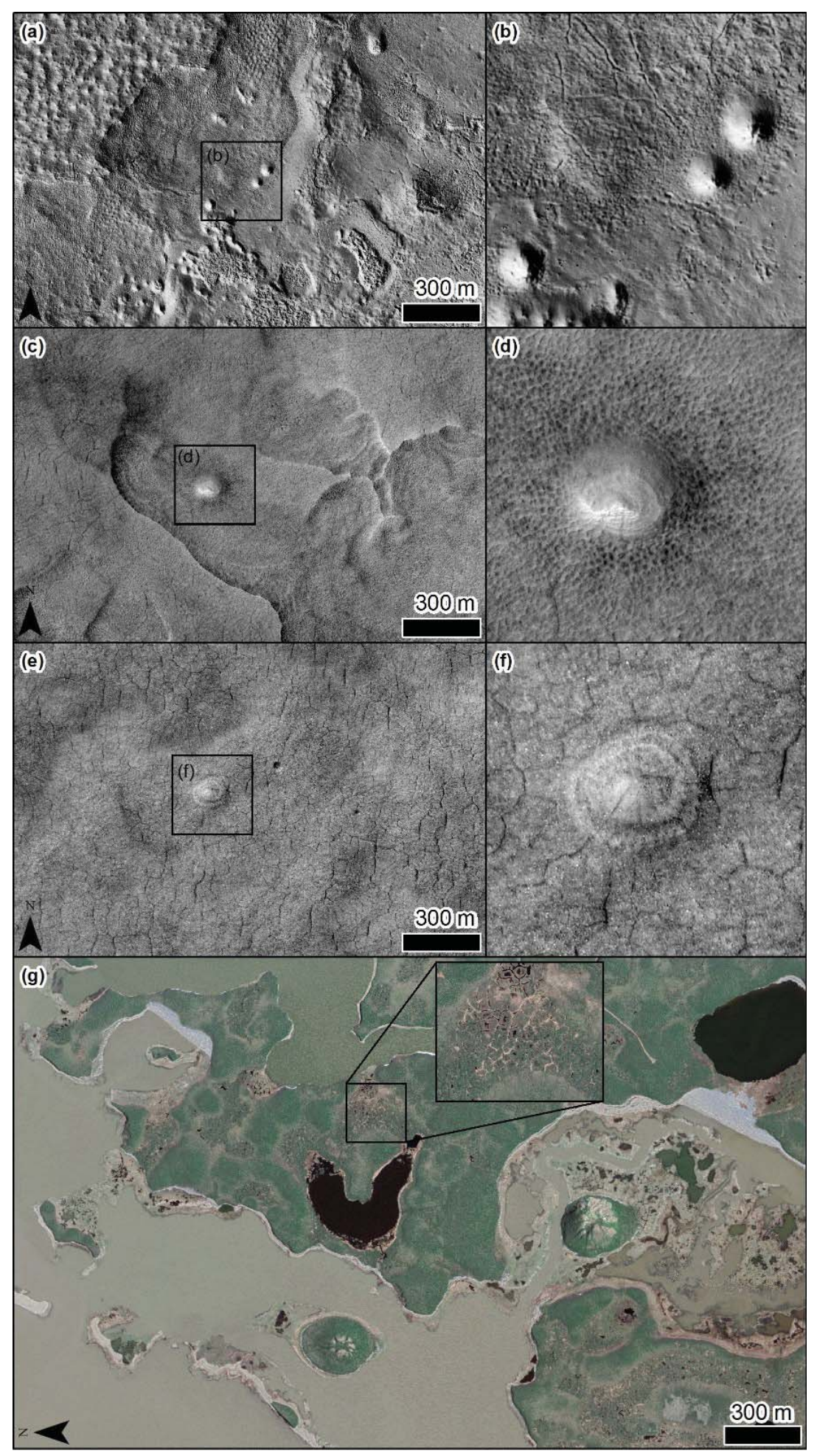




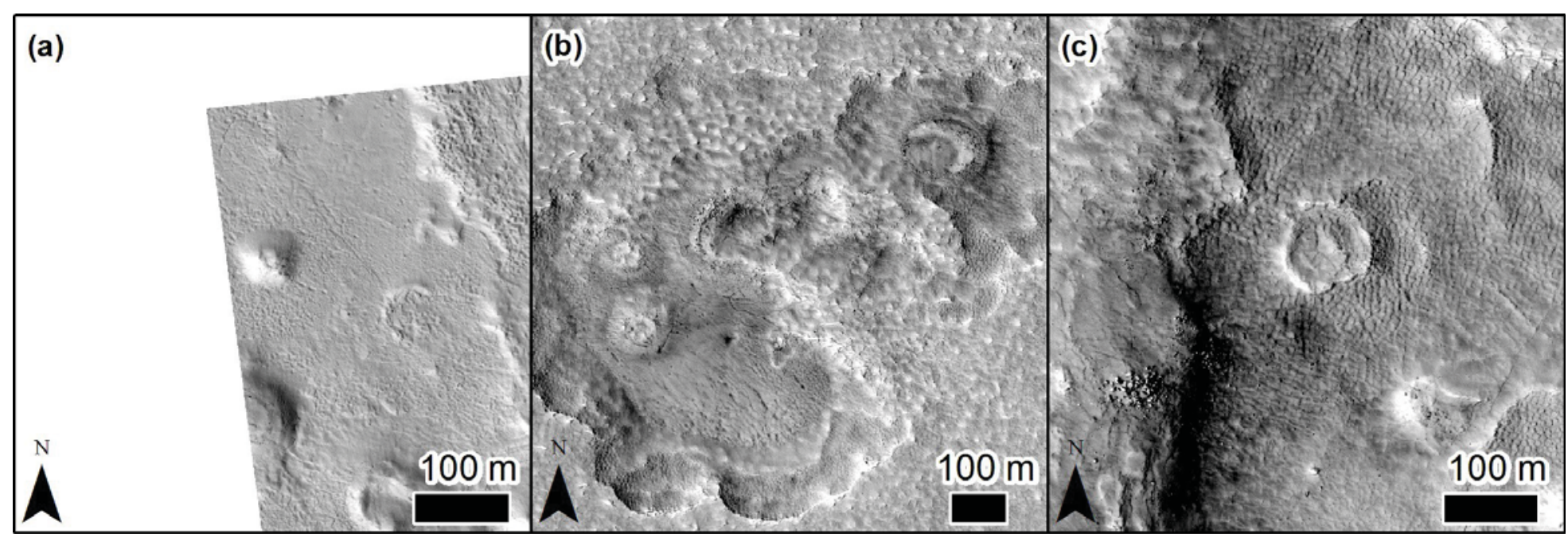




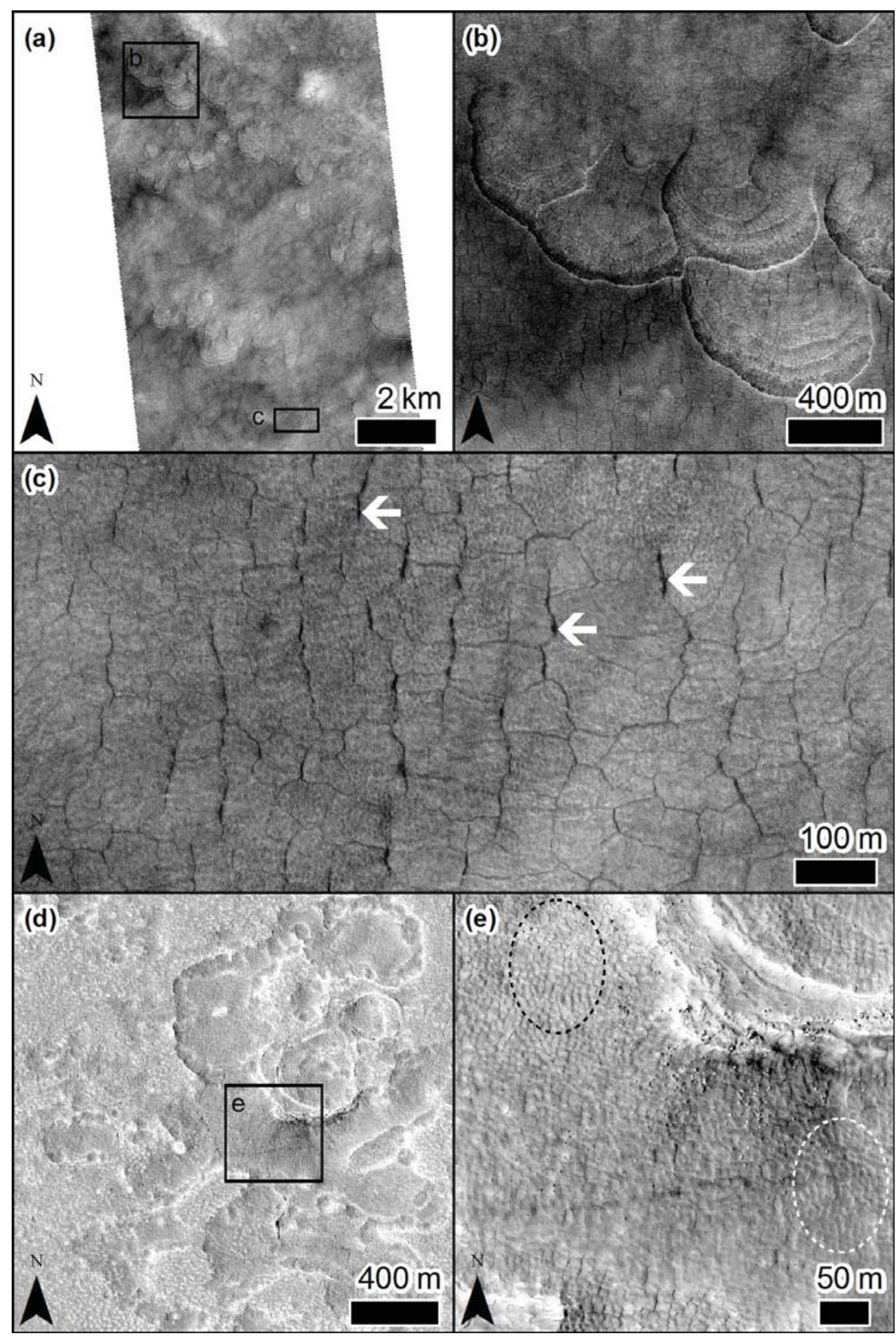




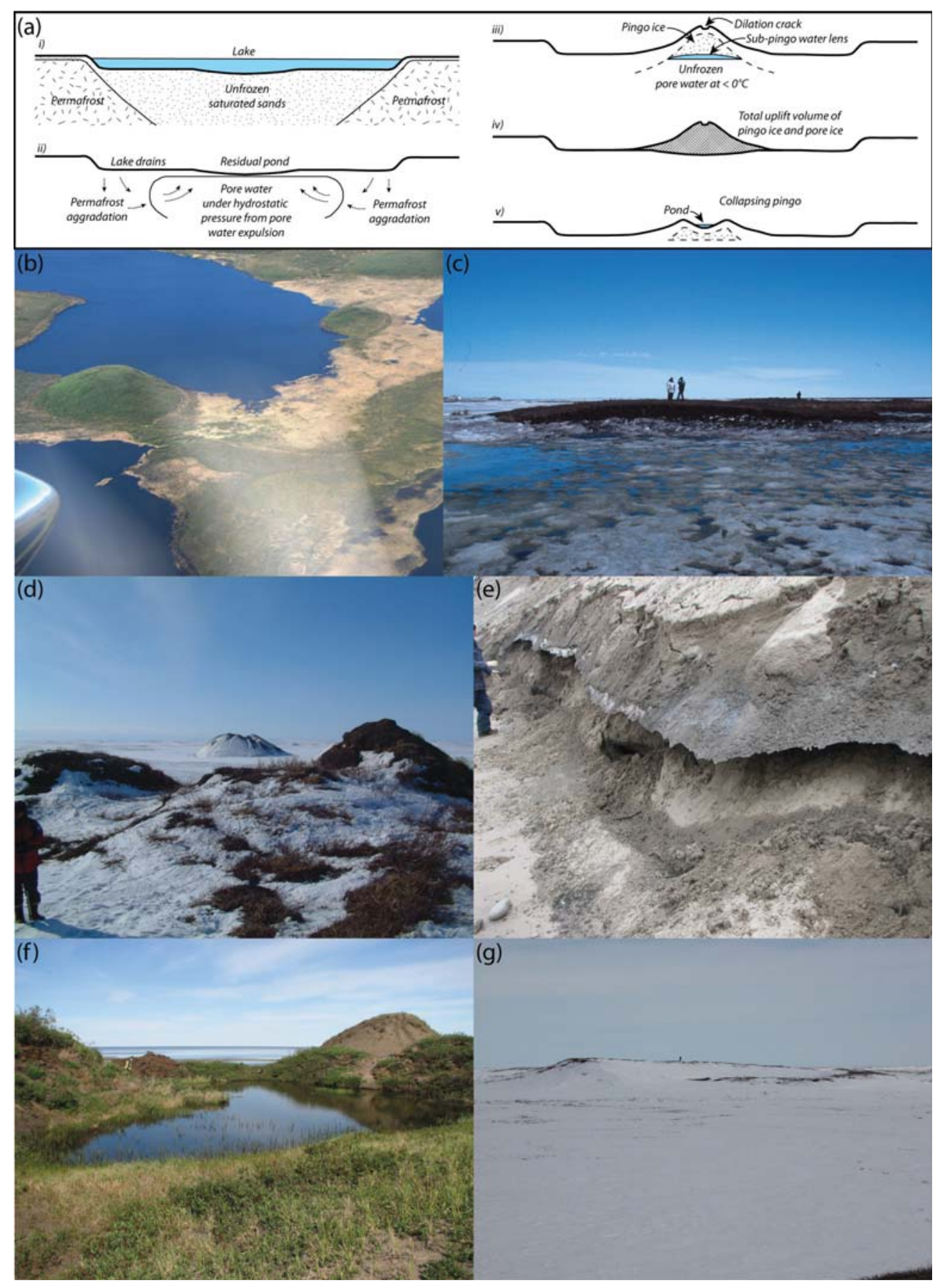



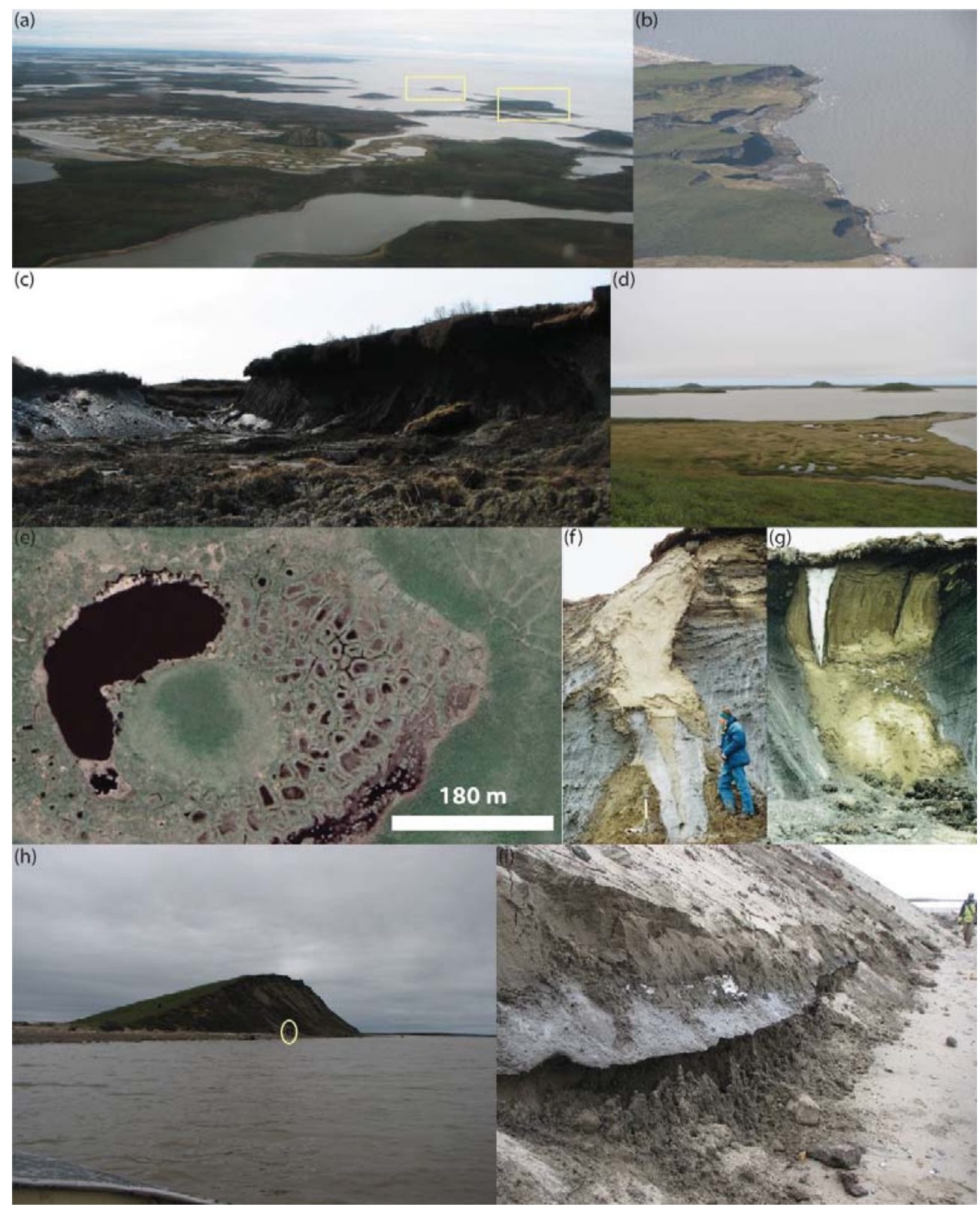


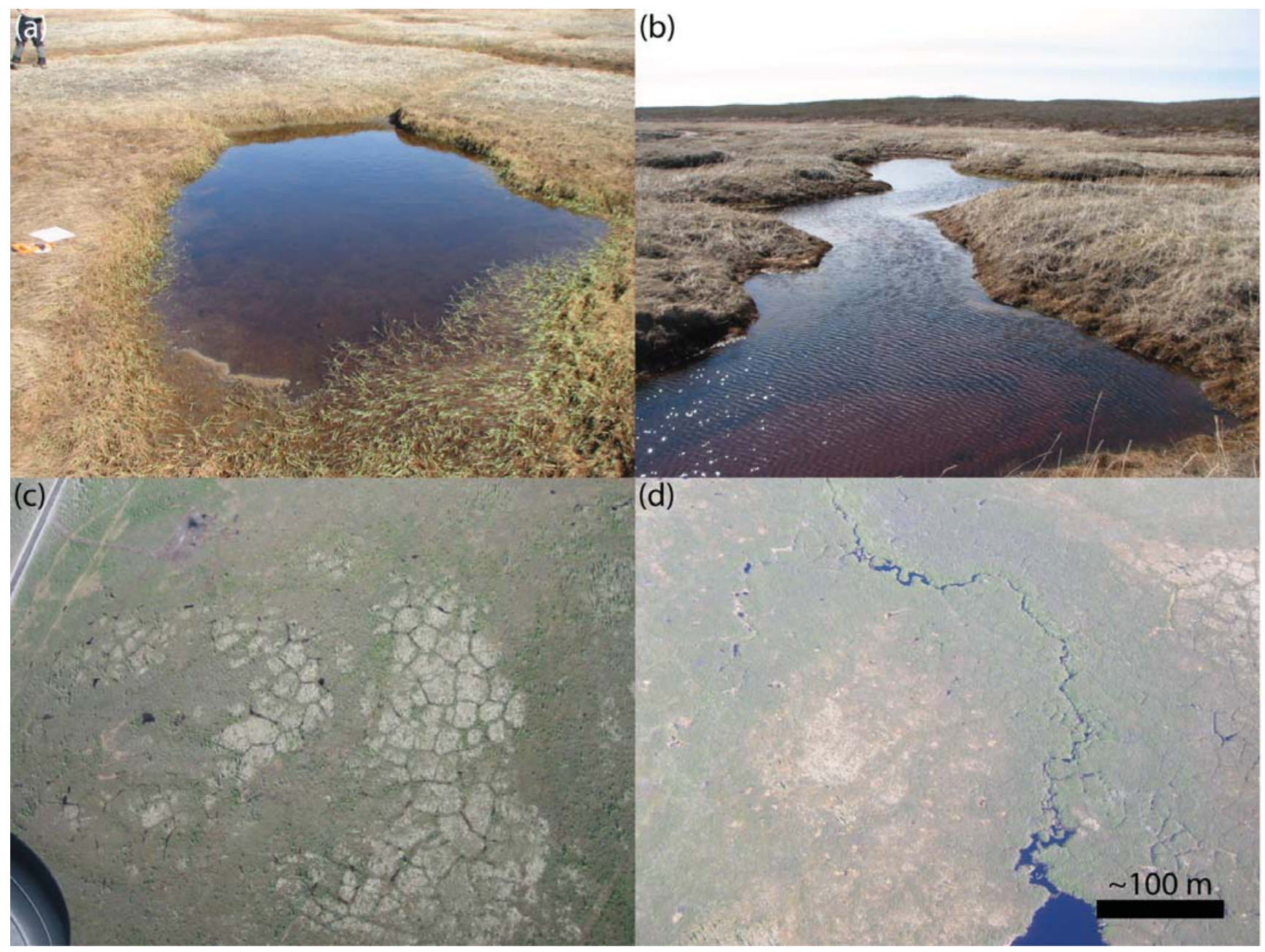




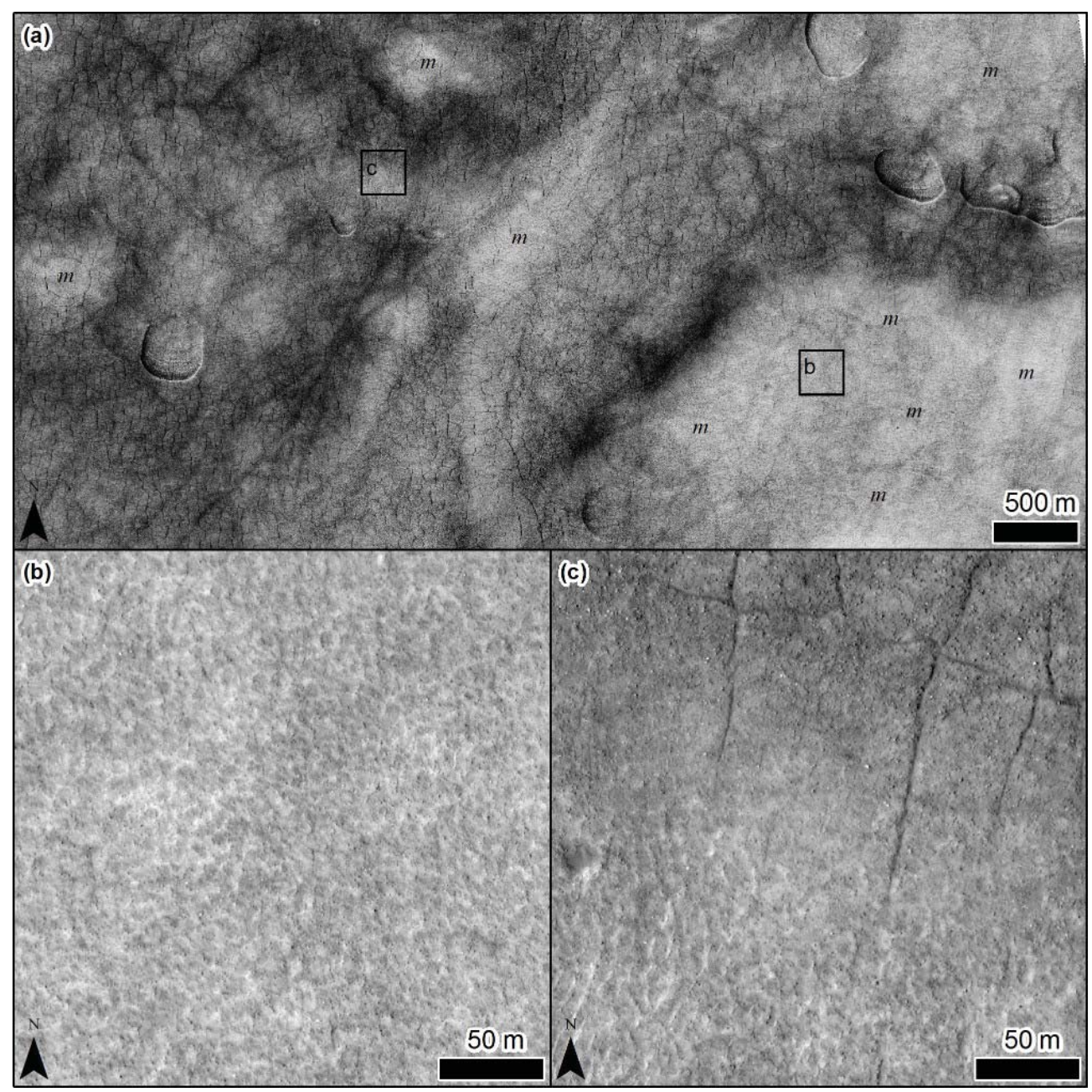



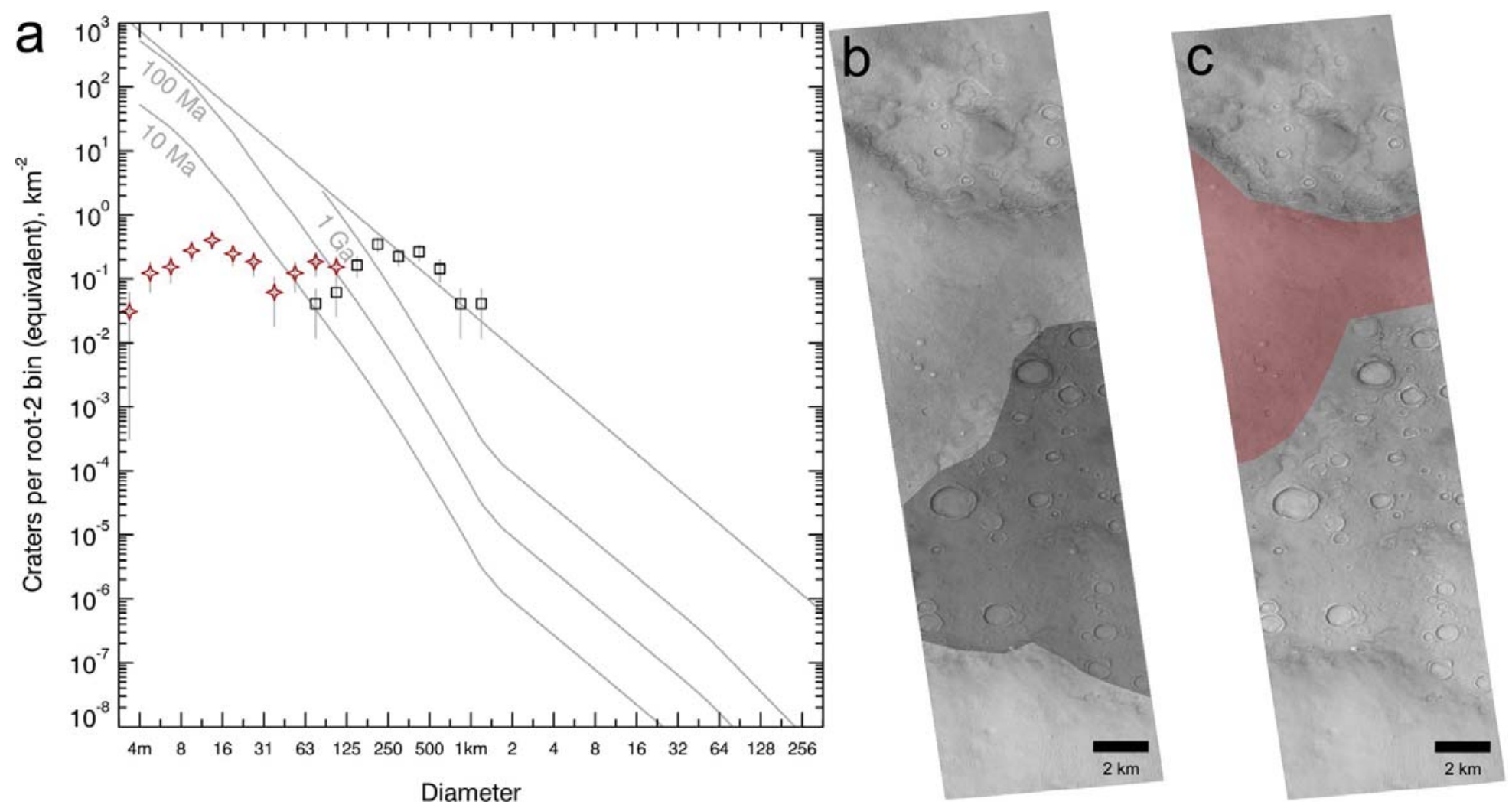


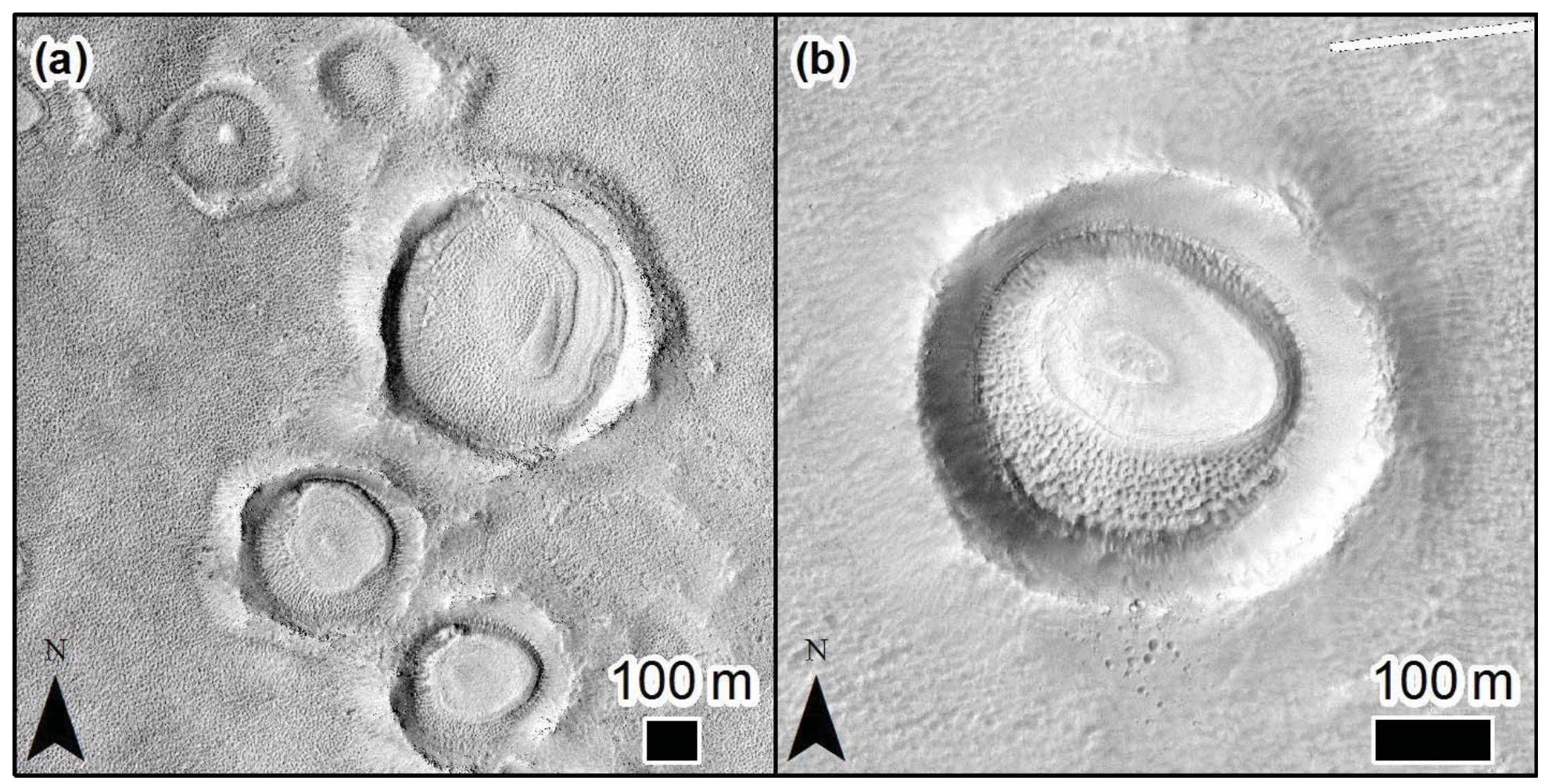




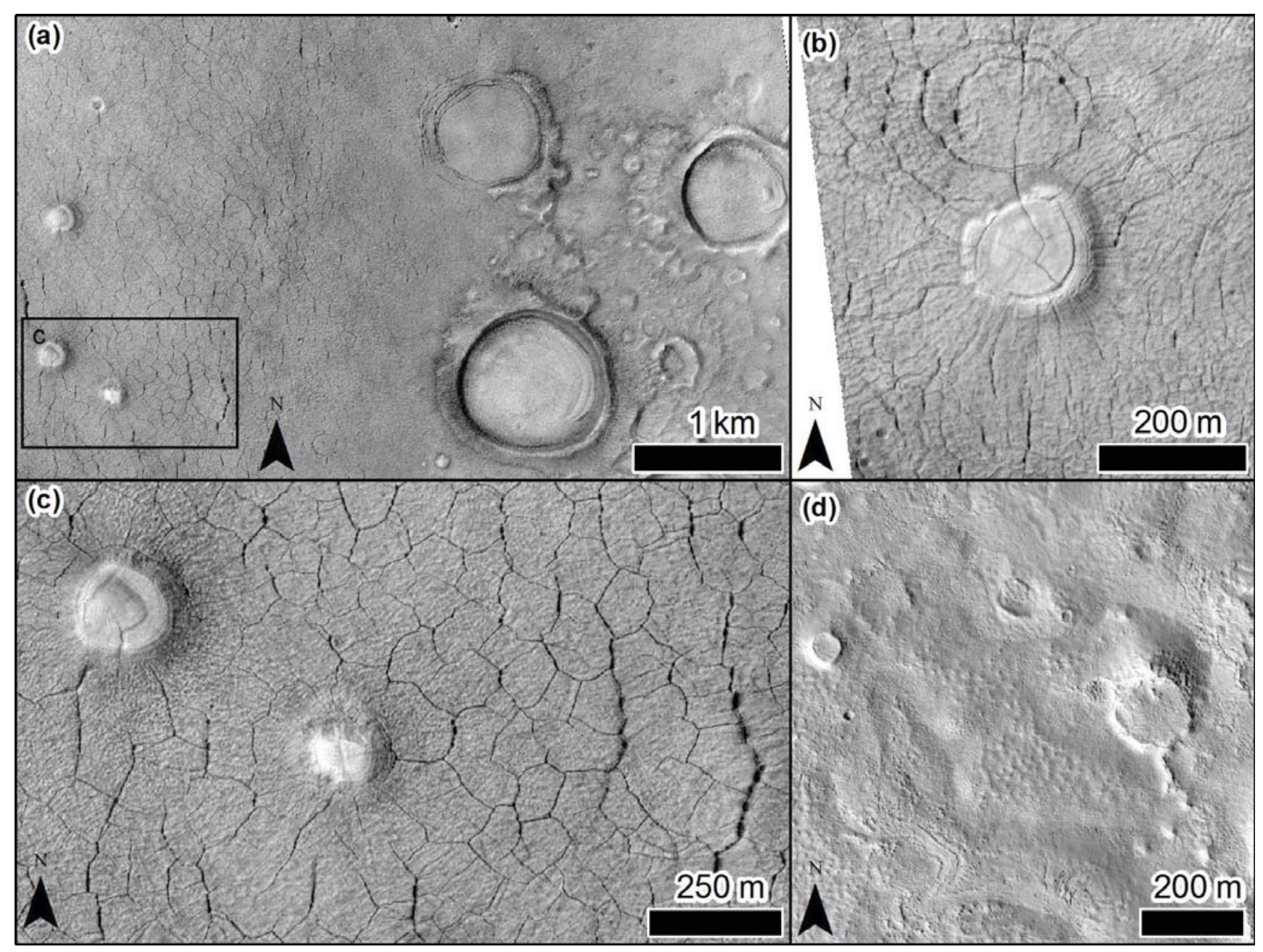


Table 1: Candidate closed-system pingos, CSPs, in the zone $35-50^{\circ} \mathrm{N} ; 80-115^{\circ} \mathrm{E}$ from $453 \mathrm{HiRISE}$ images.

\begin{tabular}{|c|c|c|c|c|c|c|c|c|c|c|c|c|}
\hline 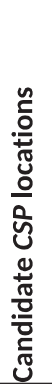 & 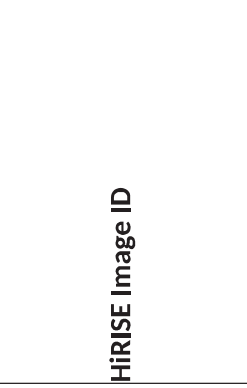 & 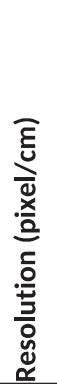 & 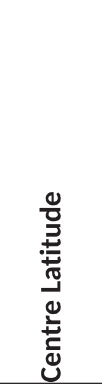 & 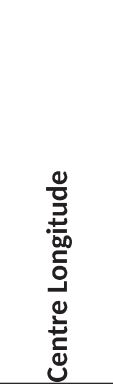 & 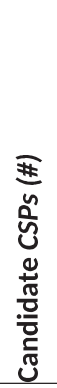 & 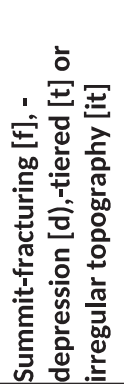 & 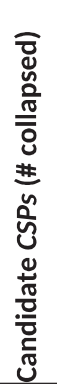 & 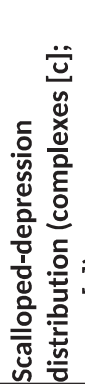 & 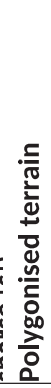 & 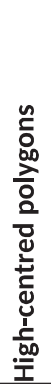 & 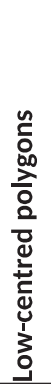 & 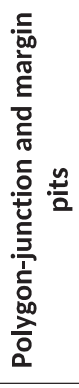 \\
\hline $1 a$ & PSP_008162_2220 & 25 & 41.583 & 82.850 & 1 & it & - & c & $x$ & $?$ & $?$ & $x$ \\
\hline $1 b$ & PSP_007951_2220 & 25 & 41.587 & 82.849 & 1 & it & - & c & $x$ & $?$ & $?$ & $x$ \\
\hline 2 & ESP_044042_2240 & 25 & 43.796 & 81.653 & 1 & it & - & c & $x$ & $?$ & $?$ & $x$ \\
\hline 3 & ESP_026556_2245 & 50 & 43.930 & 96.746 & 2 & $f, d, t$ & - & c & $x$ & $?$ & $?$ & $x$ \\
\hline 4 & ESP_055038_2250 & 50 & 44.757 & 113.888 & 61 & $\mathrm{~d}, \mathrm{t}$, it & 1 & c & $x$ & $x$ & $x$ & - \\
\hline 5 & ESP_026727_2255 & 25 & 45.052 & 108.977 & 3 & $\mathrm{t}$, it & 1 & c & $x$ & $x$ & $x$ & - \\
\hline $6 a$ & PSP_008913_2255 & 25 & 45.206 & 92.528 & 1 & $\mathrm{t}$ & - & c & $x$ & $?$ & ? & $x$ \\
\hline $6 b$ & PSP_008979_2255 & 25 & 45.206 & 92.529 & 1 & $\mathrm{t}$ & - & c & $x$ & $?$ & $?$ & $x$ \\
\hline 7 & ESP_027650_2275 & 50 & 46.479 & 112.218 & 7 & 2 & 5 & c & $x$ & $x$ & $x$ & - \\
\hline $8 a$ & ESP_053535_2270 & 25 & 46.671 & 107.139 & 2 & it & - & c & $x$ & $x$ & $x$ & - \\
\hline $8 b$ & PSP_009163_2270 & 25 & 46.651 & 107.138 & 2 & it & - & c & $x$ & $x$ & $x$ & - \\
\hline 9 & $\begin{array}{lll}\text { ESP } & 026450 & 2270\end{array}$ & 50 & 46.823 & 110.880 & 2 & it & 1 & c & $\mathrm{x}$ & $x$ & $x$ & - \\
\hline
\end{tabular}

